Portland State University

PDXScholar

$5-1971$

\title{
A Conceptual Model for a Human Resource Center for Voluntarism
}

Helen L. Warbington

Portland State University

Follow this and additional works at: https://pdxscholar.library.pdx.edu/open_access_etds

Part of the Social and Behavioral Sciences Commons

Let us know how access to this document benefits you.

Recommended Citation

Warbington, Helen L., "A Conceptual Model for a Human Resource Center for Voluntarism" (1971). Dissertations and Theses. Paper 1546.

https://doi.org/10.15760/etd.1545

This Thesis is brought to you for free and open access. It has been accepted for inclusion in Dissertations and Theses by an authorized administrator of PDXScholar. Please contact us if we can make this document more accessible: pdxscholar@pdx.edu. 
TO THE OFETCE OF GRADUATE STUDIES:

The rembers of the Commetee approve the thesis of

Holen t. Varbington presented Wy 1971.

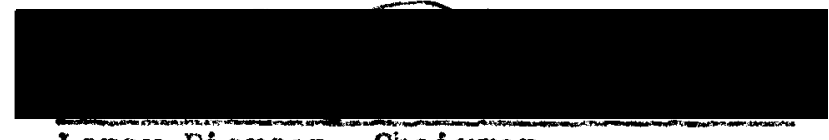

Leroy pi erson, Chairran

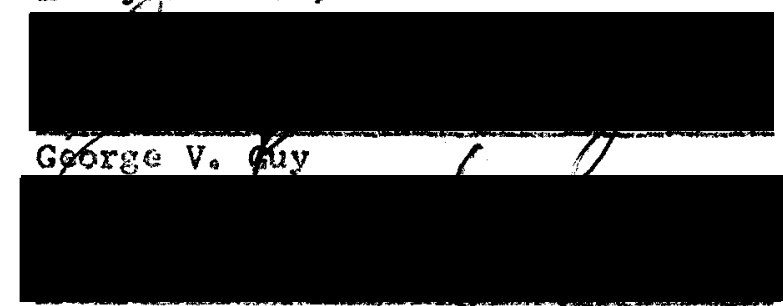

Rl chat J. Robanear

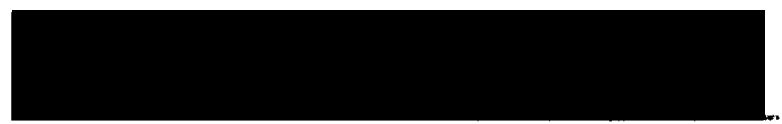

Charles Mo hrite

APRTOVD:

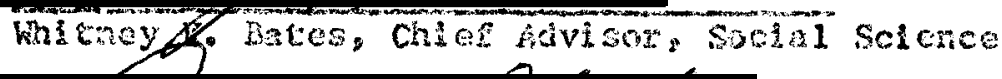

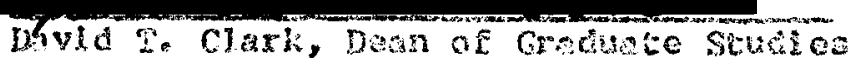




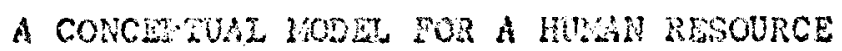

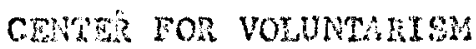

\section{by}

HETEN L. WARETKTON

A thesis subiatted in partal fulfillment of the regut renants for tite drge of

HASTE or SCJUHCE IN TERCHWN

in

GENGRAL SOCIAL SOLRNCH

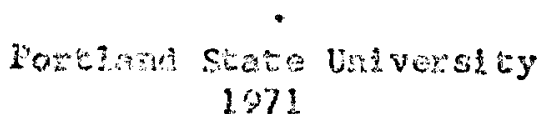

1971 


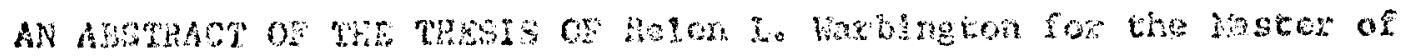

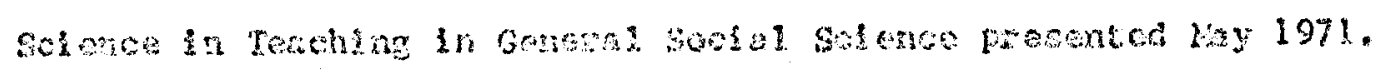

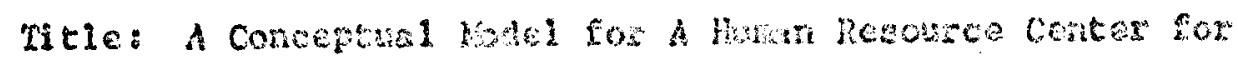

Volvatento

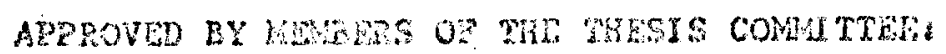

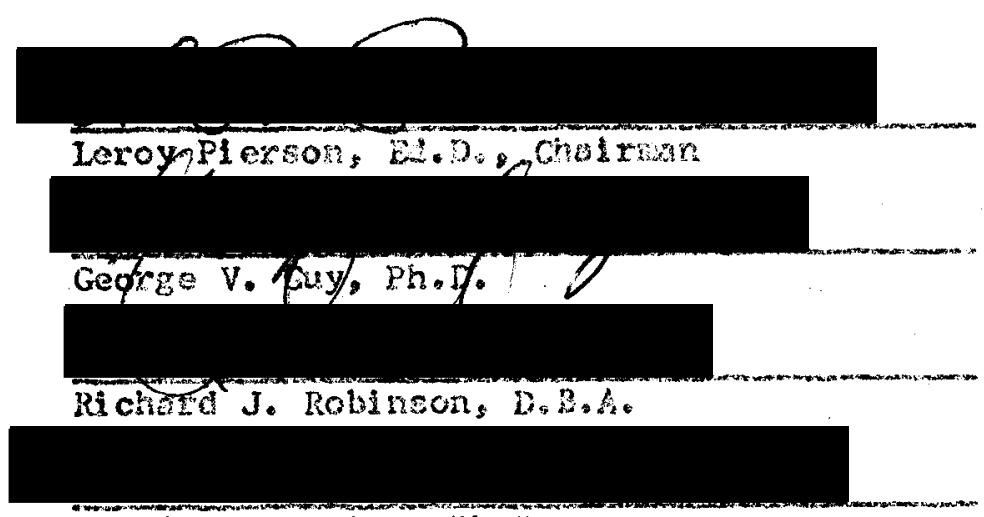

Chareles M. What PhoD.

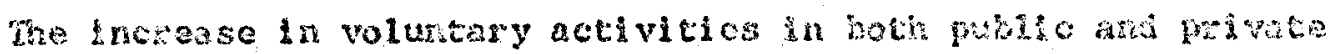

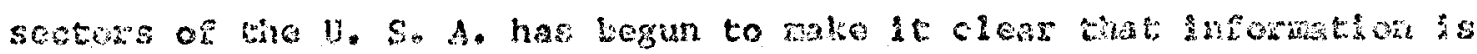

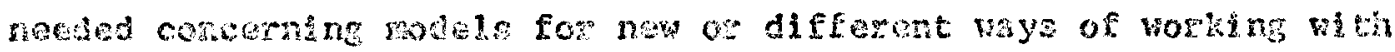
peogie fa velumed agencteo.

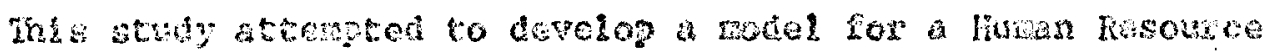

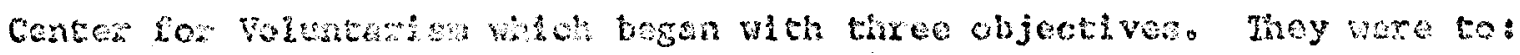

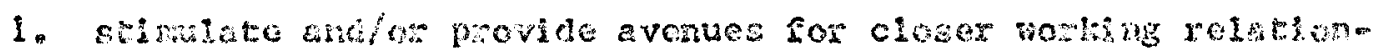

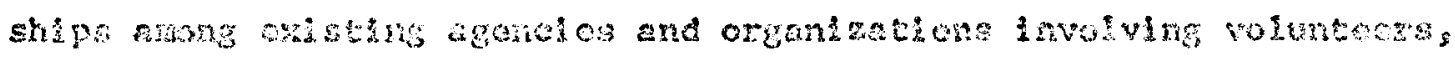

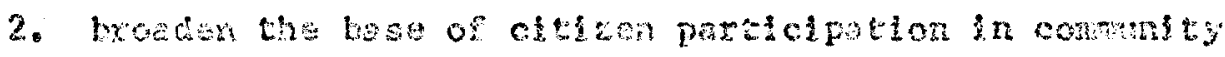
Servincos,

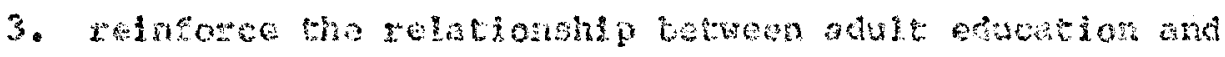

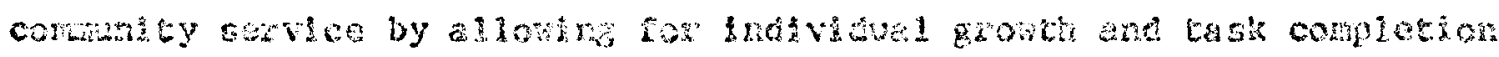

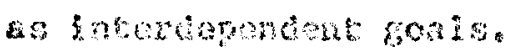


Fundanental statenents underlying the puryose for developing a Wodel included the following:

1. Involvement of citizen volunteers is a valuable facet of the American cultura! heritage, and is unigue in ite application.

2. An adult's responsibility as a citizen is to become involved in the community to woxk toward improvements for all individuals.

3. Education is the principal avenue by which this can be accomplished because: (a) learning results in behavor change, (b) behviot chenge is necessary for cultway growh and progress. Fon this, a Model was developed which described in general terms What tones, atmosphere, end rebrionships vere necessaxy to achieve bhe gonls. In addition, a proposal was sode for more specinc details bo: the reruirenents of the pirecting Group and its comporents.

Data for the study was obtained fron docunented literature primarily from 1960 to 1970 , as vell as personal caperiences of both the writer and many colleagres in the rield of voluntary comaniey savere agencies.

The witer concluced that the proposed Cancer could have sore lasting, lositive effecs on a commity by botig both a model for othox commuity servica agercios as well as an action agency which could develop innovative and experimentel weys os vork. 


\section{ACLNOLIEUCWENLS}

In the process of devejoping the content of this study, many people helped to give the author strength and courage to struggie vith the problens and frustrati ons wich inevitahly accomany such an endearor. Without these many persons, she mght still bo in the mire of billions of printed vords, esotric pluases, fumbling around in the labryinth of cross reforches, and wishing for project conpletion vithout the stimulus to carry it though.

The most vital group of helpens ging cnemagenent vere:

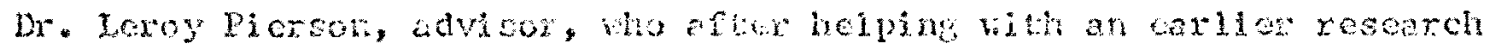

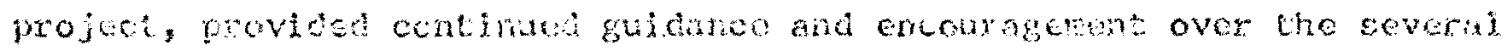
months; the Richard robinson, who grve rach time, efrort and knowiedge in thr attempt to discet the project totord chared axeas in managenent: Betty booned, who gavo onconatenent and challenga while providing oppormatice to relate some of the conoepts to practical use; Mry Conblos, tho as a carest protessional vorker vith a pivate agency. helped to identify needs, provided practical questions fux tostin ideas and thethods, and provided considerabio male buiding assistance. To thom a11, the avthor ones nuch nots then the sum total of this presentintion.

There are, of course, those who holpod in the rescarch, scheduled time to confex on problens needing attention, located motorials, and genonlly sugested aiteriztives for conduation. 
Fos: Whatever can be acecind shed ftom the smplenentation of any or all of the jdeas set forth in the lodel, end to the extent it might hels create a beter conmuity by involving, and thecero educating, achlts, the authom will oxperience satisfation from erfort expendeci.

With all of the support thus fin nomed, there was also the help and encourasentent of Heidi and Tret. Their enturanes and paticnee holyod tremendously on the last mine. It is to then I dedicate ths study. 
TADL of ConThis

PAGE

ACKNOWLDEEHNG ...................

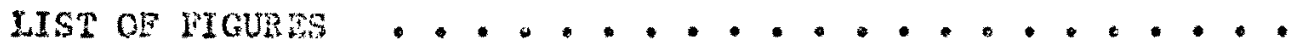

CHPTRR

I AN OVRGTH . .................

Eurposo of Eks stoby ...........

Volutecering and benocracy

voluments norined

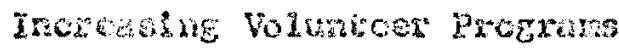

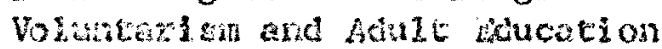

Histarienl perepectivo ..........

Develomental Gequences

Atcerptes to cooxulnate Conmunty

Serverses

Curreat scatus of vimated on

Tie Focus on Learning . . . . . . . .

Voluntec: Roles

Tisk ve. Personal Davelopment

Justification of the swey......

Nect for a Hodel

objectives

Scope of the liodel.

Developing the lotel

Applacobitry of the linen: 
II RESETRCH DESIG $\ldots$. . . . . . . .

Selesened Method

Plan for Freckntation of Vodel and Proposal. 1

Research Erooes $\ldots . . . . . .$.

Scurces of Literature

Local Data Retrieval

Relichility

Validity

Summary

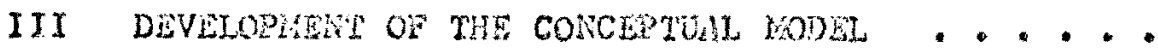

Internat end Detemal Chatactexistics .

External Dynones Affecting the Center:

Genoral Internal Characteristios

Functions of the brial . . . . . .

Functionn 1 iress

Graphl c Dasigns of the kociel . . . . .

Figure one

Figure tio

Figure Thee

Sunkmary

IV PROPOSA. FOR A HUWA RESOURCL CENTL FOR

VOTUWTRISI

43

Reletionshipe Betwoen Functions and

Opezations

Clarteication of Terss

Funstions

lange entont 


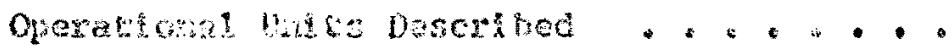

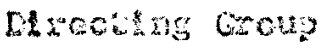

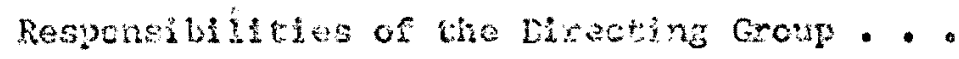

Weculdve Grow

Supporting orwps

Field reprecontativos

Tozms or Asabgriments ............

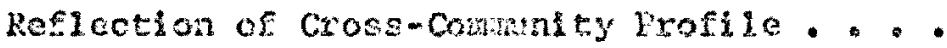

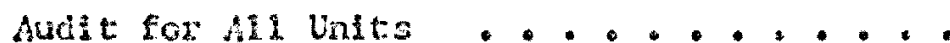

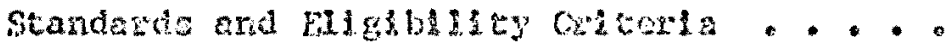

Criteria Grides

Evaluatar $, ., \cdot, \cdot, \cdot, \cdot, \cdot, \cdot, \cdot$

Types of keswitumes

Developnonial bhases ............

Gewth of ring conter

Smomary

6

V SULARK

Cenclusions

6

Commundy Changes

Intovastor and Diperimenteation

SpIn $\circ$ OfE Gronps

Interpossonal Rolations

Recomendatbans ..............

Recomberdot Gundias

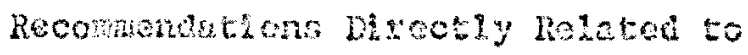

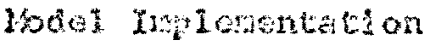

Trends Arrecting Voundestan ....... 66

RERERENCMG CITT 


\section{LIST of Ryones}

FIGURE

PAGE

1. Diagran of the Cencer: Basic Plon Linos . . . . . 39

2. Relationship of the contor to the Comminy * . . . 40

3. Possible Incoraction Arme units of the contex . . * 41

4. Interrelations of Components of bunement . . . . . 46 


\section{CHAPTER I}

\section{AN OVERVIET}

\section{PUNEOSE OF THE STUDY}

\section{Volunteering and Denocracy}

In any comanity of the $U . S . A$. tocay, there is undoubtedly a need for grester utilization of our most vital rescurce, people. The auchor"s yoars of experience in volunteor and comunity sorvice agencies, has resulted in the conviction that it is nocessary to emphasize the developnent of nuys of work of methots that help to ftll humn reets, which axe not now measured by the Gross hitial Product, or proits and Loss Sheets.

There is also a contining need to provide vitality to tite denocractic process which Lindenan compared to the vital body functions. Voluntecs ". . "are to denocracy what circulation of the blood is to the owganime Toy keep domocracy alive. . ." (1, p. 171) dre writer reallues that "domocracy" may mean diferent things to may peoplo. Honer, used in this study, demonacy is considered as a pattern of hunan relations that places the individual ard his nolfare at the heart of the whole sonial proess and considers the individunl as the end to be served rather thn as a means to be used.

Winout the active participation of cidions, the writer feels

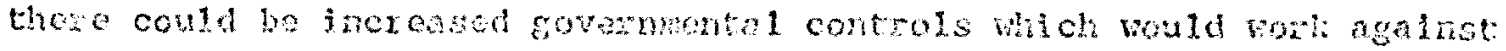
a hedrthy donocrey, end a decrease in aceptence of rcoponsibilities 
on the part of citizens which woule result in dimini shing communty involvenent.

Emphast s nust be plocd not only on inctcasing the number of people porticipating in volunteex activites, but simblancously increasing the opportunities for people to widen their vistas nith satisfying experiences in commity service. To help assure satisfoction in this service, we need to have additional or different methods which rork to mate voluntarlism nore pioductive.

One of the aspects, the witer feels, is to begin accepting different values for the results of comanity service. A completed task or project ina be a visuable goal, but there also needs to be greater value placed upon the leaning takne plaer on the part of the indsve dunls involved.

\section{Voluncori $\sin$ Defined}

Probably cormon usage has adapted the dictionsry definition of "voluntaryism" and given it to the vord "voluntarisn". Some writore used "voluntecrisn" with the same general intent as others used "voluntarism". The author found no source in the rescarched literature that actually defined the word, so a current Hebster dictionary source vas used as a starting point with the author's ow adaptations. lierein, the word "voluntari sn" will mean the following:

The principle of supporting sone communty programs or agencies, public or private, by relinnce upon voluntary action, and in which desire to help one's feilon mon is a primary factor in the experience involved. 
Increasing Voluntes Progrens

Interest in voluntaris has been increasing during the past ten years possibly at a rote double that of the provious rventy years. There appears no vay to zccuretely sosure that increaso, eithcr in anount or effectiveness. Howver, the anomt of litenture produced and the increased interest in both public and private sectors of the country Indicate considerable written and verbol attention to the reasons for voluntarism, and the need for more people to become involved.

This is probsbly because there are divergent opinions in regard to the ovex ail value of the gronth of the plrenomenon. Spiegei writes that: this is due to a lack of sufficient ". " empirical evidence from which to drav meaningful inferences and conctustons. . " "and the many defintions of the process of citizen particlpation. (2, p. 3)

Covermantal prosure is previons to "use voluteeds" with the recently created National Center for Voluntary Action secking to create a partenership ". . For an effective attacl on combinity problens... ." (3) Legislation has ciecreed there be involventent of volunteers in programs where none have porformed before. Commant Action prograns (CAP) have been attenpting to involve poverty level people in ciectsion naling. Civic and fraternal groups, whose very purposes include community service, are noving to chonge their nethods and programs to encompass a greater variety of volunteers.

These exanples and many nore have been cited by nany wrters as reasens for the rine of voluntarism, or the increased need for the rocurn to citiren participation, depending upon the wricc's phraseology and emphasis. 
Voluntoni sin and Adulg Educetion

Concurront with tho growth of voluntarist, there has been an Increasing awareness of the wher adult edveation aspects of comiuntey involvement. $(1,4,5)$

From the beginaing of the impact of voluntarisn in the eariy 1900 's, agencies were generally focused on the tasks to be done which al loved mangenent of an opezation to be authoritorian in decision making, planning and delegating. $(6,7)$ "Txaning" was the key since it has ained at helping tire person(s) complete the task with a predetermined result pictured by the trainess.

Impacts of Research. Behavioral Science has since opened nev avenues for understanding hov aduits learn, and implementation of these ideas has resulted in growing willingness to relate the role of volun tartem to the vital proceses of a vable denocratic society. $(4,8)$

In this study, the writer will often refer to this ever growing collection of knonledge, hence a definition should be clarisied at this point.

Lippite used Madia's derinition of Beheviorai Scjence as follows:

A body of systenlad knowledge percaining to hon people behave, what is the relationship berween human behavior and the total enviroment, and why people behave as they do.

In his own definition, Lippitt used this: "Behavioral seience is the stuly of the problen solving hehavior of ma", and he included subjects of Peychology, Sociology, Cultural anthropolosy, and the behavicral aspects of Political soience, Educotional Psycholozy, and Biology. $(9, p, 6)$ 
In this study, the witer feels both fefinitions working in tanden should be considered when Behavioral soienee is mentioned.

\section{HISTORICAI, PERSPECTIVE}

There is agrecnent on the historical background of voluntarism in major collections of data. This probebiy resuited from the sequence of these vorks, each one building on the others and using similar points of reference. $(1,4,8,1.0)$

In this presentation, there is insufficient value in tracing the growth of voluntarisn in a lengthy and detailed fashion. Instead, just that portion vilu. be revicwed which is pertinent to the "here and now" and that which ditectiy affects the develoment of the study.

Developuenta: Seguences.

Fron the aspect of American lifo vas the uniting of people to help each other, as well as the crganization and joining of ldeas. $(1,4)$

Coinen noted that in 1843, the Association of the Iniprovenent of the Poor in Nev York City, was organized to place emphois upon moralizing and teaching the individual to prevent parper'sm. This nas followed, in 1880 , by settlement house movenents, and was carried out largejy by upper and midue class fantlics who vanted to escape hone to mix with diferent econonte atd social backgrounds. (1) This was probobly the nixjor reason that voluntary prograns and the wealchy are equated in the ninds of both the poor and the rich. 
Eventually, in the carly 1900's, groups began to be aware of the many deep-rooted problevs within the social structure that could be eradicated only by las. The prominent group holping to relate the citizen's responsibility in this concera vas the vational council of Jewish Women. $(1,10)$

Following closely was the organization of the Junior Leagues of America, in 1921, with the youth movoments beginning in the early 1900's. These included Boy Scouts, Ginl Scouts, Cam Fire Gixis, and werc dedicated to character buhding and comintity service, $(i, 10)$ The first Council of Social hgencies was in Pitesirgh in 1908 , and the first federated fund raising and plaming body stated in Cleveland in igli. Cohen indieated these foilowed cach other closely as a result of the incuserial omexs" "givor's revolt." their wives pere ustally involved in the progrm planning portions of the commity while the men held the key to the funding. (1, pp. 39 - 48) Uniting the many fund drives, through federated funding, helped coordinate both segnents of social service by provlding ways for survey boards or coordinating groups to have lnowledge of what the programs vere about before seeking money to operate them.

\section{Attents to coozdinate}

\section{Communtey services}

Tirotighot the first thixcy years of the 20 ch Century, the gronth of different combunity scrvice ageneios and the nove tovard hixing staff to carry out part of the functions, devoloped rapidly and penetrated in increasing mubers into difforent pasts of many comunities. With the acyent of horld tax II, the office of civil Defence vas able to utilize 
much of the already well organized structures. ht the disbanding of this federal agency, a move was nade which joined the Association of Juni or Leagues of imerica and Commuity chests and Councils in an effort to sponsor a joint study to determine need and purpose for local, centralized scrvice bareaus. The burcaus were lijst considered as agencies for recruitment and referral only. $(11, p, 6)$

The post wax period, lith its nany new and different types of adjustments, had brought increased necd for rore social planning and cooperation anong existing agencics. In a fow commuties, this service was begun by newly created yolunteer lureaus which also attempted to alleviate recruitment and training problems. Dy 1951 , there vas an Association of volunteer Buronus in existance. (1, p. 49)

A compenensive study of the growth of volunteer Bureaus is not included herein. Suffice to say that in 1958 , there was a 1 ist of 92 Bureaus in 32 states and the listrict of Colunbia (1), and the 1970 roster of the Association of Voluntear Bureaus of America recognized a total of 140 in 37 states and the District of Columbia. (12)

\section{Current status of Voluntari sm}

In April 1969, the Presidential statement which resulted in creating the National Progran for Voluntary Action has since expanded into Voluntary Action Centers. (VAC) and the accompanying conferences, talks, and volunes of witten data on the subject. The impact of the govermentel decree to involve people in new, innovative ways, has resulted in a growing desire to drop some of the tratijtional mothods, but there is still sone confusion abote the rew directions to take. $(3, p, 3)$ 
Traditional. agencies have hoen findirg it difficult to continue traditional programs because of changing needs of communties and insuffictent change within the agencies. Self studies have been initiated by some major agercies in ordex to close the gap between need and prostamed service.

Tho outstanding exarples of this are the MMA in their quest for relevance and subsequent redjrection of progran, (13) and the Gir1 scouts of the U. So Ao in their new training program. (14)

Pressure is on all the agencies, whether or not they are nationally affiliated, to refocus their programs and chargo priorities.

An area of agreement secms to be that the "lady Bountiful." stereotype is not nov acceptable. This title bas been used to convey the idea of the rich giving to the poor, and that ratexid woalth equaled supexio ority. The author consicors this a poon aproach to hunan relations, especially as it concorns the involvement of voluntecrs from different econonic levels.

\section{THE FOCUS ON L.FARNING}

With the many years of active participation as a practltoner in volunteer agencies, there were tro arcas which repeatediy frustrated this writcr, as vell as sone colleagues. They vere: 1) an interpretation that described the nany and changing roles of volunteers as the Volunteer Role and its relutionship to the Professional Role; 2) the practlee that determined the completion of a tast as the first priarity, and not the development of people, thereby often liniting the opportunity for many parsons to become invelved. 
These two polnts are clocely relatod, but each has its own axea of involvenent. Eoth concern the velationohips of voluntects and staff mernbers, and the need to shite prioricius.

\section{Volunteer loles}

These are pexcelved in very diffeient vays even by sim lar type agencies, and yet there appears a strong tendency co categorige a person as either a "policy moker type" or a "progran type", in populaz handbooks and guides. (4, 8, 11) There is also variance in regard to the amount of rosponsiblity and authority volunteers share with the staff (or prow fessional) vorkers. $(15, p, 6)$

Current Scudies. Sone studies have begun to question the effectiveness of sone of thi crabitional nodels. (10, p. 58, 15) The result is that viters ate suggesting that mäy persons can be both typss, feel the need to be in both roles concurrentiy and be successful in those roles. Naylor $(8,0.41)$ suggested that there shoula be closer exami.. nation of the shatp divisions male in polley making and program implementation, in regard to volunteer participation, in oxder to enable each person to bettex understand these two phases of theix cm operations. Loevenberg (16) studied the type of partichation in ". . the critical decision making pooess associated with organizstonal charateristies. . " He found that the wore complos, the greater the budget, the grouter relance on start leports, the laner the ageney, the less substancive the preticipation in the decision riaking group. Douglah (17) tricd to detemine if there were relationships in adult patedeation betrean ducaliona astivg and voluntary formal 
organizations. Or the many finding in the stucy, he found differences in motivation between male and femle pextchrots, and a high correlation between inercased amount of fomal coucation and compunty involvenent. Thete vere, however, no allusions to the specifle role played by voluntecrs.

Task vs, Personal Development:

This phrase has been chosen to title frustration Number To. From personal obsorvation over the years, it has obvious that nany persons wanted to help in some vay, to "do good", but many ware not ready or in the right task area for thef current aptbudes os interests, and within one agency, there uften appeared no "right spot" for too many people. There also semed to be froquent conflct betwen the task completion and the growth or readiness of the voluncess. loo often, the staff planed the task areas without the volunteers heiping to develop the requirements or task responsibilities. (15, p. 6)

Highily skilled volunteers as well as staff vere dominated by the pressure to complete the task since measurement of their success often, if not alwas, was evaluated by this tangible result. Lip scrvice was paid to developing people, to involve then, to help them learn, but when a staff position was measured by the results of increased nembership, or quality of events, the satisfaction of wathing a shy, frightenco person learn skilis beyond his or hex expectations vas difficult to share with those in judgnent of the worker, and who vere unable to view the trancformtion firstiand. 
Persons of low lnowe who could not afford to volunteer vere left out of the game completely. Thore va little of no chance for tirse citizens to eatch up with peopie who has growa up in the fillosophy of giving sorvice and loarning fur fun.

Current litorature continues so stress the importunce of the reckitment, traking, plecement end treatment of people vorking as volunteers. Yet, none seens to provide adeguate liodels for a total systen or plan to assure that results rould neet the neede. Insterd, challonges aro ropeatecly rathen that we rust find ways to accomplish this with fon, if eny, concrete joeas provided.

For crample, in references by both Nylor (8) and cohen (1), staterente wee given deolwring the nools as well as loolotirg soga of those arcas. The writer foum no spectite suggeselons ox ideas vinis vould gute interested groups in thex atterpt to develop systeme

The kah (18) study for Rea ghborhood information Centers was a 1itrle nose relpful and provicd ideas, but did not assomble then into a possible total patcon. Gudelings (19) provided a partal plaring secned to vork against soma of the neceseary objoctives this author felt must be pare of a mode1.

\section{IV* JUSTIETCATHON OH THE STUDY}

Wh the consldereblo awout of conedn cres duplicatlon of efforts, hilile concurrentiy, loud polces vere complaining of too nary volde in human corvloos, it ne oblous to the moter thot now and differenc weys met be developed to crowsege citizen involvement in 
commity service. These involvements also had to be alloved to grow from the point at wich the participints vere, not always from the points where others thought they ought to be.

The study, then, needed to begin with a conceptus l model, which by example and system, would provide inpetus and guidance for that which it professed to promate.

Need for $A$ Vodel

Research in cursent 11 cerature was done extensively, in order to discover a precedent for this type of stwy. (Soe chapter II) in searching for an eficotive conbination of ways of rork and objectives, the writer found fragronts of ideas which vere helpful. Hovever, none nere

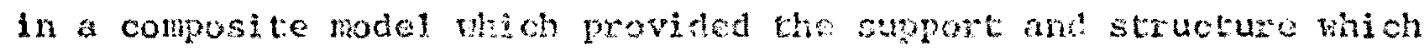

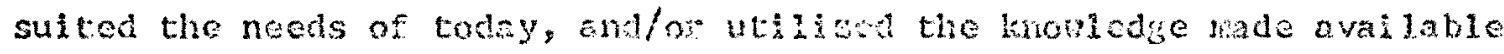
by nunerous behavioral science studies. It seened, then, that contributions to the growth and development of a strong voluntecr movenent: would be enhanced by the creation of a motel wich included practices now in effeet, as well as those which tay have been pagt practices, along with the impact and latitude of new, experinencal approsches.

\section{Objectives}

Before creating the Conceptual lstel, the vis tex deternined the objectives toward which the Nodk1 showld work. Three areas nere, to the author, gemane to the colic: 1) development of nore offective relationshys arong exasting human service agenches, 2) involvenent of greater nubbers of citizens as voluntecrs, 3) recognition that effectivo adut learning must be condidered as a vital commoty sorvice. 
These werc then refince ins follovs:

The objectives of the concentual lodel are to:

1. Stimulate and/o* provide sventes for cioser working relationships awong existing agencies and oxgantzations involving volunteers,

2. broaden the base of citizen participation in communlty services,

3. refnforce the relationships between adult education and commity service by allowing for individual growth and task completion as interdependent goals.

Scope of the Mode1

Further derintion of the functions, characteristics, and required operationa practices preceded the design for the Model. These had to bo detetnined before appropriate structural patterns wore refined since they becone the tone and intangibie elements vitai lo any organiation: dealing with people. These are found in chapter iII.

\section{Developing the Model}

Building a structure for an onganacion which could utilize the objectives and, as an entity, service the total comunity, was the nert step. This evolved into the structural deslgn for the conceptus l wadel. for a Hum Resomec conter for Voluntarism, and is found in Chaptex III. Applicalitity of the Bodel

Although the jocal data was gathered from a distance of approximately 100 miles radius from Wetropolitan fortand, all in the Washington and orowon gocgraphical area, it was velghed and reasured against 
documerted 11terature witton for vider audiences. From this, it seened that the Madel, bosed upon both praticn? expowence and these documented studies, could be adapted to nost commities with simlax chaxacteristics, such as metropolitan areas and smaller urban developments, no matter where they were located, if they were in the same national sphere. The Wodel was mont to be usod in the present time wi th current knowledge of huthan behavior and developnent, and with no greater vor ld or national crises than presently exist.

\section{v. FUNDHENTAL STREMENTS}

The bodel needs to bo consicied whin tire framowom of the

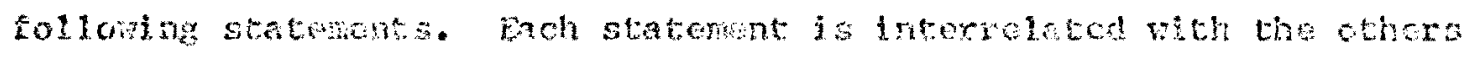
and togecher they stoce the riter's rations lo for propesing a model which enables thetre continution and ixplemation,

1. Invelvement of citigen voluntecrs is a valuable facet of the Anericen culture? heritage, and is untiue in its application.

2. An arun's responibility as a citizon is to becono invalved

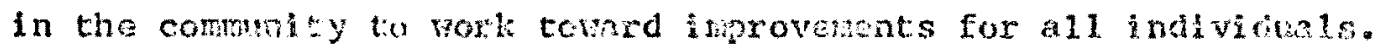

3. Education is the principal avenue by wich this can be accem plahed and te must take every avat lable fown to curther the objectives of the wded. This is further reinforced becauses
a) learning results in behevior changr:
b) bchavior change is necesary for calutal growh and progress. 
Involvement of citizen Volunteces

To understand the kodel for A Human lesource Center for Voluntarisia, there must be an acceptance that voluntecr clizen involvement is an extenslon of our denocratic systeng and must exist in ali parts of the commity. Comnon accoptance has included the political arena, at least to the privileges and responstbilities of voting. The trend tonard local involvenent has begun to bo increased with programs being established wich encourage local determination in the implementation stages. This is not intended to nean that a11 proyrams should or could be carried by volunteers, but rather that every individual should have a role in determining sone part of his or her comemity action.

\section{Adule Responsinility}

The increasc in oux population and the vastross of our teckich development, serve to make it more difficult for indivisals to find ways to work toward the comon good. This is primaly due to con flicting ideas in regard to what is good for the commity in both short and long run programs.

Each person, howevar, must have the opporitunity and be encowaged to become involved in the sphere of influence he or she can accopt and comprehend. This my rango from the small netghbortood group to the world atena, nud is inherent in the fuericen concept of government, "of, by, and for the peoplo." (10, p. 8)

Voluntarisn in the sense of cition participation and involve-

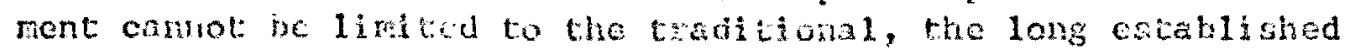
so called 'power structures' of the cormunitiss. . . This fuvolvenont in the total contmity in problen solving for their own velfare has ben called the hei votutarism. . .' $(10, p .8)$ 
The current trond is avay fron the eurifor accepted "Iady Bountirult concept and is port of the rooth with has been termed by some writers as mlightened self Interear, excmplificd by the intent of some current anti-povercy prograxs. (10, p. 8) Though the first stages of volunterisn vere done in the spint of vell intentioned patemalisn, ". . done by the rich who thought they knew ancutelvaly whe vas best for the poor,. . "the videning reah for volunteors is one of the field tests of thethex or not ve are ectualiy able to practice the denocratic coneepts ne greach. (10, p.9)

\section{Educetion for Involverent}

Acceptance of the staterant that iceming results in behavioral chrnge does not predeternine the style of retrobology of the leaning procese. Resoreh has etrit not solved the question of thich method or system is best under speetic conditions. (20) The point is that iearning is vicol to progress and change, and yot one of the arens Insciequately explored in rteld laboratory tests concerns ciucation resuitant fron the ind vidual's involvonent in comanty service netivities.

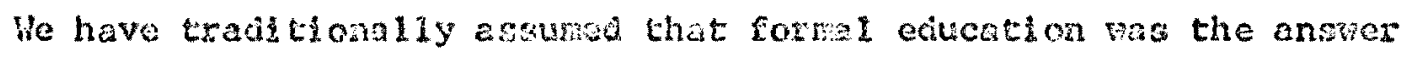
to cultural covelopencte. However, tas incresse in tho nubcr of agoncles

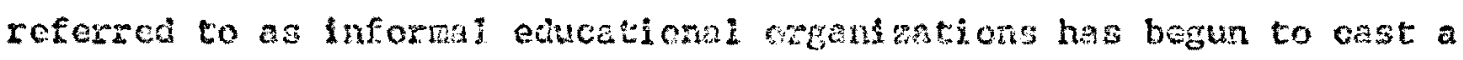
new light on the ways to lom, and subequanty on the values of voluritanes.

Bergevir, in his ruest fot a phlowophy for Acult Education, based

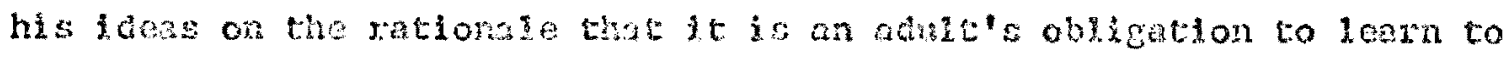


becone a nore productsve citszen, to icars hot to better accept responsibility in political, vocational, physical and spixitual realins. (5, pp. 4 - 6) Adult education is a hons to crabie the develophent of free, creative and responsible persors ard to ". . advance the human motivation process. . . 'i (5, p. 5)

Stenzel and feency, in theix book on volunteax training, felt that the opportunity for poople to have a continutry ". . College for citizen participation.." is found in conmunity organizations. $(4, p, 20)$

Cohen desci ibed volutiarisn as a lohoratory of Denocracy and developed that thought as it relates to strengthening learning. $(1, \mathrm{FP}, 22-26)$

Spinaler, in spcaling of the anthropological trend tonard crossmeniturai studice of eciucation, took the stand that:

Education in this focus is the proeess of transwitting culture -- Including ski11s, knowledge, attitudes, and values, as nell as specific behavios pateerns. It is the culture of the human being, where culture is used as a verb. (2I, p. 58)

\section{SUMMARY}

As a nation of people, ve have said ve vant individual participation and that it is a citzen's responsibility. We have also begun to recognize that eduction conss in many shapes and sizes. The writer feels there reeds to be increasing attention given to the implenentation of these fundarental statenerte in orcies to help penetrate heretofone undeveloped areas in our commitics. 
A plan for the utilination of mman resources, whin the objective of helping people gros whithe contributing to others' neds, can work toward providing moro aventes for dithon involvement. 
CHAPTER IX

\section{RESEARCH DESTGN}

\section{DREINTNG THE AREA}

Fev sources wore found to define the difference between a "citizen participant" or "volunteer", though most miters alluded to then repeatediy and interchangeably. Cohen $(1, p$, vii) sumed it up by saying "A citizen volunteer is one who assumes voluntarily and wi thout pay his obligation of citizenship." Spiegel refors to it as a phenonenon cailed "Citigen Participation" and dyrantally states that 1t is:

a fhonomonon of infinite complexity and subtle dinension. - - Evcry effort to reduce its protean-like substance to a deftnable, systematic, and comprehonsible body of thought is resisted by inherent dilemas -.. contradictions between myth and reality and even between differenc sets of observable social phenonena. Cicizen participation virtually defies generalization and delights in reduesing abstexetions to dust. $(2, \mathrm{p} .3)$

He further undorscores this by stating that there is insufficiont cmpinical data, and what there is often is coutradictory, inconclustve, and too localized to ba of general value. Bas is the factor he feels causos the blocks to setentific appronch. (2, p. 4)

Cohen (1, p. 33) sumarizes the vionotint most witers have used which is the amport: ve arguraent.

The volunter experience should provide, along with the fecijug of boing vilued as an indiviturl, a chanee for meningful paricipetion and an intorstelcation of a sense of social responstbility. 
He lists the novenent roward the scientific and technical as a threat to the vory institutions' pupeses for int ch they vere founded. They become, too often, the ". objective, the impersonal, the intellectual, as distinguished from the subjective, the persconal, the individual, the emotional. - It gives us the vorld of description, not the world of appreciation. . ." (1, p. 33)

In spite of the conflicting viess, spiegel conpled a variety of materials speaking for and against the process of citizen participation, which was an effort to present docunentaton to help understand the phenomenor as it is being observed in wban developsent.

The concern felt by the witer is the increasing need for ind viduais to difect at least a small part of thein chn destimy. The size and distance of government, the specialibetion whtch is evorywere, the increasing data aval labie in every field of lnowledge which has to be shared to be effective, all point tovand the need to try and provide a mediwin for people to learn more about directing themselves, and to find ways to help each other. There is need to try to humize the urban enviroment, and there should be no limit to the experinentation for ways to accomplish this. (18, p. 11)

\section{RATTONGE TOR SULCTED FORTIT}

\section{Selected Method}

It: becane obvious fron the material researched that the appropriate format was a foraulatye or exploratory category as defined in the reference, Research Nethods in Soctal Pelations. (22, p. 28) 
This appraach is used when ". . the prime purpose is the formulation of a problein for more prectse investigation, or the development of an hypothesis, ox the establichnthe of proxities for furcher: research. . ." (22, pp. $28=29)$

In this gutcie, Jahoda, et a1., diviced the exploratory category into three parts: 1) revich of haterials related dixectly and indirectly to the social science subject chosen, 2) surveying experienced practitioners, 3) analyang cases or examles to gain insight. The authors further dexined this study aproach as being flexible in approach, and allowing for ". . extensive study of a wide variety of matorials rather than rigorous control of the situations studied or prealso masuremant of the factors involved. . ." $(22, \mathrm{pr}, 28$-29)

Following these guidelines proved to be useful in the research of voluninous anounts of literature on subjects which could be related by inferonce even if not in theix exact forms.

\section{Plan for Presencation of} Model and Proissal.

Using all the possible alternatives for this research approach, local interviews and meterials vero recorded as vell as data from 1iterature on a wide variety of related subjects. Experiences of practitioness, including the writer, provicled material for a foundetion for judgments in detemining practicality or application. These vere selected there appropriate to underscore, reinforce, or furthor 11lustrate specific parts of the lodel. 
The vodel is firet given specific chavacteristes and functions, then presentad in gxaphic design. Imedlately folloving is a proposal describing the detalis of the compononts, ax mits, of a Human Resource Center for Voluntarismo

Current trends affecting the implementation of the propusal are placed in the finel chapter along with the author's conclusions and recomendations.

\section{RESEARCH PROCESS}

Greater enphasis nas placed upon dooumented 1itemature than on intervicus with, or practices of, groups, The reasons for this were reliability as well as accessiblity of data. Though thero could bo some operation, somemare, uing part or all of the taeas in this study, there vas ho reacomble way the author could determine this. In addition to research in books, periodicals ot strit.ax docunented data, conferences and intervieus pome hold with the practitioners within the aforementioned geographical area. The raminder of the nor-cocumented data vas from the witer's vork experiences with cormunity agencies and their personnel.

\section{Souress of Litcrature}

Educaliong pesources tnermation Center. This syster, usvally referred to as ERIC, proved to be the nost helpful. Two nicrofiche collections were located, at the the of major research in the sumer of 1970, in the city of Pontland, oregon, and proved to be the only thorough method of obte ning deta pertinent to the subject aron. 


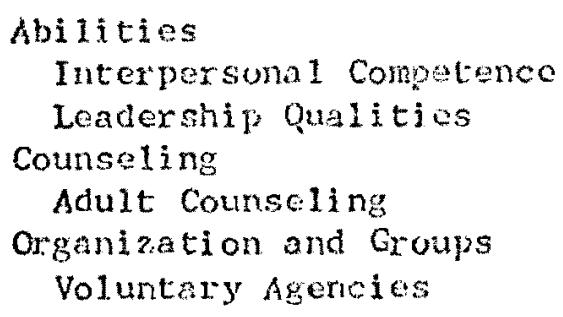

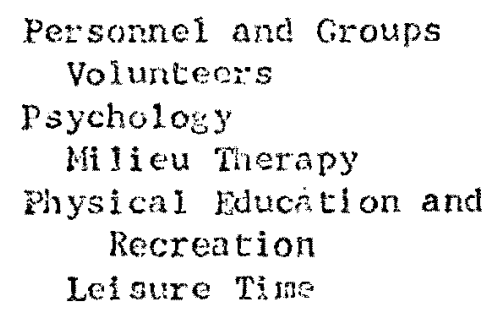

ERIC Classification and Bibliography. Both ouring the criginal data collection and subsequent recording on jnciex cards, the classification system of ERIC proved very beneficial. The reference numbers and letters for those works cited were inctuded in this bibliography in order that readers inight refur more easily to the mi crofiche materiass cited. Though not a standard prosedure, it was considered appropriate since the fomat for formal papers kas developed prior to the ERIC plan. Doctoral Disgertationg and Msters ireses. The American

Doctoral Dissertations ${ }^{1}$ was researched using the stre subject aress as in Enc and ineluding the yreas 1065 rreugh 1060.

Wasters Theses, in the Masters Abstracts of Selected Theses. were researched under the subject groups of Education, Sociology, Public Velfare and Sociology, and included the ycars from 1967 through Mrch 1970. These proved to be of little value since there were only a fow theses listed in this subject trio and none vere pertinent. It was of interest, howcvor, that ERIC listed many of the hasters Theses whoh provided additional and pertinent references. The bias for selection in the Hasters systern just mentioned may have ruled out nost of the subject: areas not considered in the classtcal world of Academin.

${ }^{1}$ Botih of these sentes aro printed by xerox Elucation tivision, University horofinns Library Service, Am Arbor, Michigan. 
Current Index to the Jound in Education. This sounce reforred to as CIJE was generally a duplication of the litcrature listed in ERIC. Hovever, spot checks vore made using the following subject headings: Attitudes, Administration, Standaris, Abilities, Cominucation. Inderes inclucled were 1968, 1969, and Jamury, Fobruary for 1970. Host of these stucies or articles vere written for forml education rather than the informal world of voluntarisin, hence, vere not of primary value to the student secking current data in an area not recognized as "disciplined".

\section{Local Data Retrieval}

Prior to and duxing the formal rescarch in the area of documented 1iterature, local information was gathered. Thas inciuded prepared

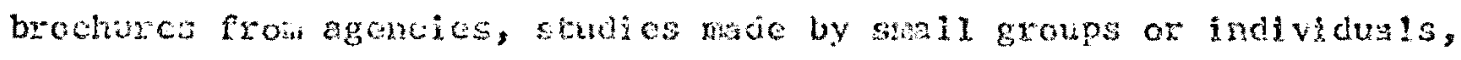
and confercnees with persons actively lrvolved in solve form of rolun tarisn through organization, agencies or clube. Ench source was recorded and macle part of the retrieval systen to be used if needed in the final witing.

Volunteer Survey. An unofficlal survey contueted in 1969 under the general sponsorship of the Oregon Association of Volunteer Leaders, Fortland Chapter, vas made by the Facuity Wives' group of Portland state University. (24) This study involved a telephone survey of about 120 Metropolitan Portland agoneies and attempted ta determine if those agencies would be interoster in persicipating in a volunteer Burcau, if organizod, and included an effort to sain information concernting the training and utilization of voluteer personel. 
The general resulcs inticated the majority of agency personnel contacted felt their agoncies would profit by sone form of agenoy though there vas considerable variance in the perception of the services such a new organtzation might provide. There vere also wide variations in regard to the approach to training and development of volunteer personnel. The data seemed, to this wricer, to indicate ronger froll little or no system to well developed plans with the former category in the majority. Adu1t Education Research Project. During the early part of 1970 , this variter comploted research in adult chucation in oregon and southwest Washington to determine if local connunity agencies used the resources of other agencies in thetr adult ectucation programs, what percentage of membership was involved in learning events, and what type of supportive assistance was provided thoss tho helped others ientn. (25)

Pertinent results showed: 1) of tho 23 respondents, nore than half incicated they rarely or never used resource people or materials from other agencics; 2) priarity was placed on organizational objectives and Improving specific skills or tasis vith general self improvenent rated 1oi or not inportant. Those rating the latter as important placed emphasis upon profescional improvenent; 3) the percentage of total educational effort was about equal in teaching nev starf and new volumteors, with a few agencies indicating they spent iess than $50 \%$ of their efucational hime on experienced volunteers or staff; 4) the responses were even in the rumber providing comseling in regard to helping people chouse appiopriate louning events. About two thirds of the respontents indicated they hold post-particlpation counseling. 
Oregon dssociation of Voluntegr leadous. Knowis as ofv, this loosely knit, but effective association vas formed in 1967 to try to help unite the many agencies aiready utilizing volunteer personnel. (26) Three chapters were eventually formed, contered in salem, Eugene, and Portland respectively. Fach had as its first major goal, the organization of a volunter Bureav within its cormunity jurisdiction. The Portland Chapter developed a Citizen's Comitten which, in January 1970, submitted the proposis to OAVL and subsequently to the Tri-County Comminity Council, for a Volunteer Rureau to be formed which could serve the wider Pothiand area.

Wuch of the stabilizing support: for the onvl came from the unique conbination of staff from the Division of Continuing Erucetion, the local Council of Jewish homen, and the Junior League of Portland. At this writing, the arganization is in the stage of refocusing its purpose and function wi thout diect support from these groups. Citizen's Comitice study. In January 1970, the above mentioned proposal was subuited to the ru-County Commanity Council, offices in Fortland, outlining the purpose, rationale, and basic budgetary requirements to establish a voluntecr Bureau. (27) This document resulted from considerabie stuily of the previous experionce of local bureaus and factors relative to the current need for sone central organization to recruit and refer volunteers. The vilunteer survey conclusions had been utllyed to obtain and doctment the interest ard support for a Bureau.

Do Sorpting Project. During the surnex of 1970, the portland Junior Chonbat of Connexce membersh began to make plans to conduct a 
recrut thent campign for volunteors. (28) Criginally unaware of the Citizen's Comittee proposai, this Jayceo project intended to get: people involved through a massive recrutment dxive and dixect refenral system. Before final implenentation of the "no Something" Campaign, the two groups coondinated their projects to the extent that sone information was channeled and roles vere clarificd. The club's own evaluation of their first attempt at the project shoved several week areas, though at least one more year's effort was pledged.

Conforences and Intervievs. During Juiy 1970, visits were made to three Northwest Volunteer Bureau offices, in Eugene, Seattle, and Tacona. Interviews vere held with each of the three directors, Information and naterials obtained and revieved. The purpose of these contacts vas to leam general informtion about the agency structures, cuxint programs and objectives. There was ro plan to develop depth studies of each operation unless there had beon unusual or experinental. projects undeway relative to this study.

Numerous conversations vere held with other $100 \mathrm{l}$ persons in regard to their ideas on voluntaxism, the development of an organization which unght serve as a vehicle for cooperative efforts among existing coninunity service agencias, and their reactions to specific ways of work. These were logech and kept for reference as ideas only, and not as documented conversations. Due to the personal nature of all of these conferences and intervisw, the autho: did not feel st served any helpful purpose to designate the souxecs by names or agency in this presentation. 
Personal Experience No one can question that personal experience carries with it a large anomt of hies and subjective evaluation. Honever, it can also provide a considerable backlog of material for developnent of a model, both concoptunl and applied. Attempting to use this kind of data reguired an exfort to contimuliy evalunte the recollection of the setting, the dynamies of the intexpersonal relationships as viewed by more than one person. Evaluating why a structure might not have been effective can, at best, only be measured by Individuels or groups with whom comnunication has taken place. A persotul conviction of the merit of the objective or goal still velghs heavily in the rinal outcome, which places subjectivity in an influential position.

With these lindtations in mind, this somce was stil used for the developinent of the lodel.

Reliability

In an exploratory study, a substantial amount of data should include the survey of experienced practitioners. (22, p. 28) Reliability of their answers vas tested in the following ways.

Effort was mede to ask similar questions and delve into similat areas of the vork of the intervievees, ic. systems of internal controls, methods of recruiting, methods for person-to-person contacts aud communication.

Securing locunented matorials from the intervieves vas sufficient to assure that verbal deliveries vere in balence vith witten ones. In cases of commication problems, thore vere shared efforts to clarify by rephrasing, or restating. 
Reliability of 1 iterature rovence vas controlled by using the same categories and delineations in the many different sources of data. When these appeared diffornt, cross"checking vesulted in being assured that synonym vere essentially the same in intent, if not exact verbiage.

\section{Validity.}

Since there fere very few local survey on questionnine types of data gathering involved in the study, theze was little attempt to validate these neasuring inghuments. Those fow wich wete cited vere indicated as boing ony trend indicators in genoral subject areas.

In tius project, there vere judgmental positions taken by the writer. The lodel was based on a series of components, some parts of which lave been teeted and mplemed over sovomal yous' time. The other components are based on what hos been dommented in the behaveral scicaces and can be considzred valid, Combining these into a general Model was the result of the witer's on jutgwents and perceptions.

Since it is not foasibje to control the greatest variable, people, it wosld be inecurare to say that all of the answers, conelusions,

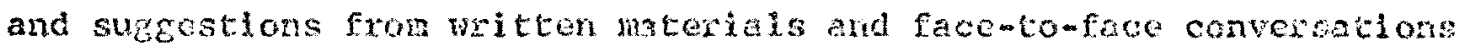
would be scientiacally valid, since another point of view could analyze and predict different results. There was, howsver, a constant effort to locate sufficlont data from litenture to validate the three parts of the objectives of the study, In adition, there was a consistent effort made to explatin each unit and to conter variebies of the rotol to the

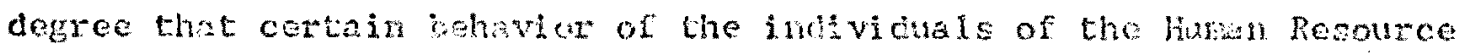
Center could and would thely occut. These wore done by suggestions of 
ways of work which would allow and even stirulate the unification necessary to achieve the objectives of the Center.

\section{SUMHRY}

A search of the documented it terature wos the primary source of information for this witer. Hovever, there vere also local sources which provided both contrasts and exanples for examination.

In all the research, the author did not feei the criteria for the Model had been ather recognized or met in any one example of service to the comunity. From this conelusion, a Moblel vas doveloped in acidion to a proposal for spccific structure. These follon in the rext two chspters. 
CHAPTER II

DEVELOMBNT OR THE CONCBPTAE WODEL

Before the structure of the lodel could be completed, the writer designated specific characteristics and functions which vere requisites to nacting its objectives. After listing these, the pattern and design of the structure vore cham. Esscitially these characteristics and functions beame the scope, or outer linits, of the Model, within which the structure vas designed. Detalls for the Proposal for a Human Resource Center for voluntarism follows in the nowt cheptex.

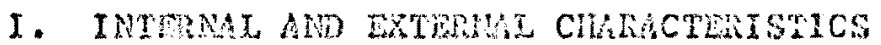

Though structuie can provide avenues for netting objectives of the lodel, recognition must be constant that certain condlions, interpersonsi dynamics, and qualities are desireable or inherent in the Viodel and its using agencies. These characteristics and traits affect the prograri, which nuztures and mantains the human services in a commity.

\section{Extornal prenics Affecting the Center}

A Conter nust be ahle to accomoriate grest variatlons in the agenciea wioh are potontial users of its services. This writer feels there are fout mor categolies for cunsideration, as a result of adaptations male from the stonzel and Feeney zeference. $(4,1 p, 2-3)$ 
1. A vide range of interests would exist fron youth groups to Sentor Citizen Ciubs, From garcen clubs to health prograns.

2. Different approaches for delivering services would be used by cach of the particilating agercies.

3. A great vasiety of activities nould be inclucied in the several using groups' programs, with a nixture of titles for similar things.

4. Organizational structures vould vary partially due to progran peculiarities, traditions and custons.

\section{General Internal Chameteristics}

Flexibility. A structure needs to be developed in such a way that program action 1 s more important than the machinery which facilitates it. Such puactices as creating terminal task groups rather than only long standing comittees, and involving resmurce persons on short tem advisory tasks help prevent the operation from getting lacked into only one way of work.

Stability. Rules of procedure should be fen but succinct, wht legal requirements of local, state, federal governments met: wh th uncomes plicated documents. Develoment of simple guidelines for task groups should exist instaad of long, complicated lists of vays of work. The Node1 must demonstrate the interpecsonal trust and cooperation omplified by close vorking relationships among all units. Stebitity can be as much a state of mind as vittca docunents upon which unts are expected to rely for total guidance.

Genera1 Chataoteristics. " To assure floxibility and stability, additiunel qualitses met be recognace and anticipatod in the buiding of the structure ardi fion lines for commoncabion by components of the 
Model. Adaptations from the qualities sugested in the kahn study include: $(18, p p \cdot 35-37)$

1. A constont open door atuosphere and a ferling of welcome needs to prevail for any using azency or intividual.

2. Expertise should be available in every possible area. This does not mean that every participont met bogin vith expertiso, hovever.

3. A constantiy increasing range of information and program should be gathered.

4. There needs to be an absence of restrictions in service to different sochal classes. The profile of a glven commity should be the only limiting factor in providing services.

5. Confidentiality should be employed whond where rentirad.

6. Caxe should be excrcised in regard to being non-partisan and non-scetarian. This should bo discussed frequently by specific functions of the policy making group.

I1. FUNCTTONS OF THE WODEL

Before final determintion was made for the bastc functions, reforences were examined for examples. Some listed oporationar areas among the furctions wich sented to this antior to be duplications of task areas, (11, 19) other listings inoluded broad statements of purpose but did not provide surficient defintion of specific functons. (1, 8) After syathesining data which secmed appopriate, the writer detomined that the kidel should inctude five functional areas. Compositely, these becane the purpose for which the hadel existed, and 
provided the foundation for a structure through which progran could be developed that would help Eulfill the objuctives of the hodel.

Each function is mont to operate both intemally and externally, though in varying degrees at different thes. Ilistrations of these follow.

\section{Functional arees}

Recruitment and Referral. The broad spectrum of recruiting, interviewing, screening and referring becomes the method by which there can be a constantiy increasing base of involvement. Recruitment of people can be both internal, to operate the Motel, and external, to fulfill the requests from using agencies.

Education and fyeining. The ongoing education of operators of the Center is requiste to individul giowth. providing stimulus or gudance for learning experiences invelving external groups, or using agencies, results in the dual role for this function.

Coordintion. This role shauld be carried by several unts of the Center and involves people, places and things. Such prograns as learning events and services to commity, which fall within the chjectives, have to be considered as part of this function. Internal coordination is mandatuy for the total operation, and rust be constant. Extennaily, this function is concerned when the Conter becones involved in any using agenciee' prograns.

Research and Study. Ioca: needs, current and futuie, locaI opportunties mich help ind anent prograns of the center, volds ant duplications in services and nanporex, ald should he anticlpated so that 
plans of work can be nate which assure short periods of tine between stated needs and their fulfillmont.

Consultatioi. Strengthening agencies' services, providing guidance in program development, and helping to xalse standards of performance, can all be part of the externel consultive function. Helping an agency to initiate its first volunteer program nay be a vital need and one which can be implemented.

Consultation may also be internal, as one unit helps anothex, though the majot portion of this function would remin with the external agencles.

IIT. GRARIC DESIGNS OE TH MODEL

In the following pages, the Nodel is didgramed in a series of three seprate figures. Strweturing the botel with the necessary characteristics, as described earlier in this Chapter, can be done only partially in this graphic forni. Hence, additional suppotive information will immediately follow these designs.

In each of the folloning basic designs, the reader should note that flow lines could be drewn in any number of coninations. To keep the destgns stmple, these vere not shown. Interaction botween support Groups, Field lopresentatives, and the Executive Group could be frequent or infäequent, depending upon tho program of exch unit.

A brief explanation of the vorkine components of the Model vill be given here in order to help the rerde beter understand the grapha designe. 
Support Groups comprise the ongolng ox ad hoc task areas of the Nodel which are supportive to all outex units.

Field Representatives axe individuls representing specific types of service agencics,

Executive Groug is the nare given to the component of the Directing Group which is enpoveret to make interin decisions.

Directing Group is the explanatory titie used to describe the entire body of individuals directing the operations and plans of the Center.

Figure one (see page 39)

This design could be changed by ading or subtracting field Representatives, either by combing catczorles, or elininating some, depending upon the cothunity's need and or growth developwist of the Wodel.

For example, if the Directing Group is not able to recruit a volunteer for the Comanth Planning and Developmont category becouse of insufficient interest shown by local groups in the evolving volunterr programs, rather than leave a vacancy, the category should be elininated until such time that need arlses.

Figure mo (seo page 40$)$

The functions of the centor are statod earier in this chapter and again in Chaptex IV. The graphic design attempts to show the Center interacting with the commity and fielding requests to the appropiate support group in the centor. 
These functions can be better performa by the center than by any given agency because those groups have particular programs to pronote and specific goals and objectivas. A "noutral agent" can scrve in tho multi-roles of catalyst, intiator, trainer, stimulator, and intensive recruiter, whout pressure from peer organizations. There is usually a fear for survival and too scldon vill an agoncy initiate requests for help from its peer agencies.

Figure Throe (see page 41 )

An 1lustration, simplified, shoving the possjble interaction between two support groups and a Field Represcntative is used herein to represent the direct scrvice action which should occur. Timing is the vital. factor in this type of trancaction. Mancs" arise quickiy even though "necds" have extsted for months or years. Rapid action must be possible within a structure becase interest wanes quickly if credibility is doubted. Credibility is often lost men orranizational processes move too slowly.

Should a need be detcrmined, wut the recipient does not share the attitude of the finder, there may be dialog, searehing, coping and confrontation in order to establish an acceptable direction. $(9$, pp. $1-5)$

Conversely, an event buing throm togather fin haste can damage future events of the center willo mitsing the target for which it was aimed. In this illustration, three major units of the conter vere in communcation with the requesting ageney, hence, would have kept quality and purpose in check. 


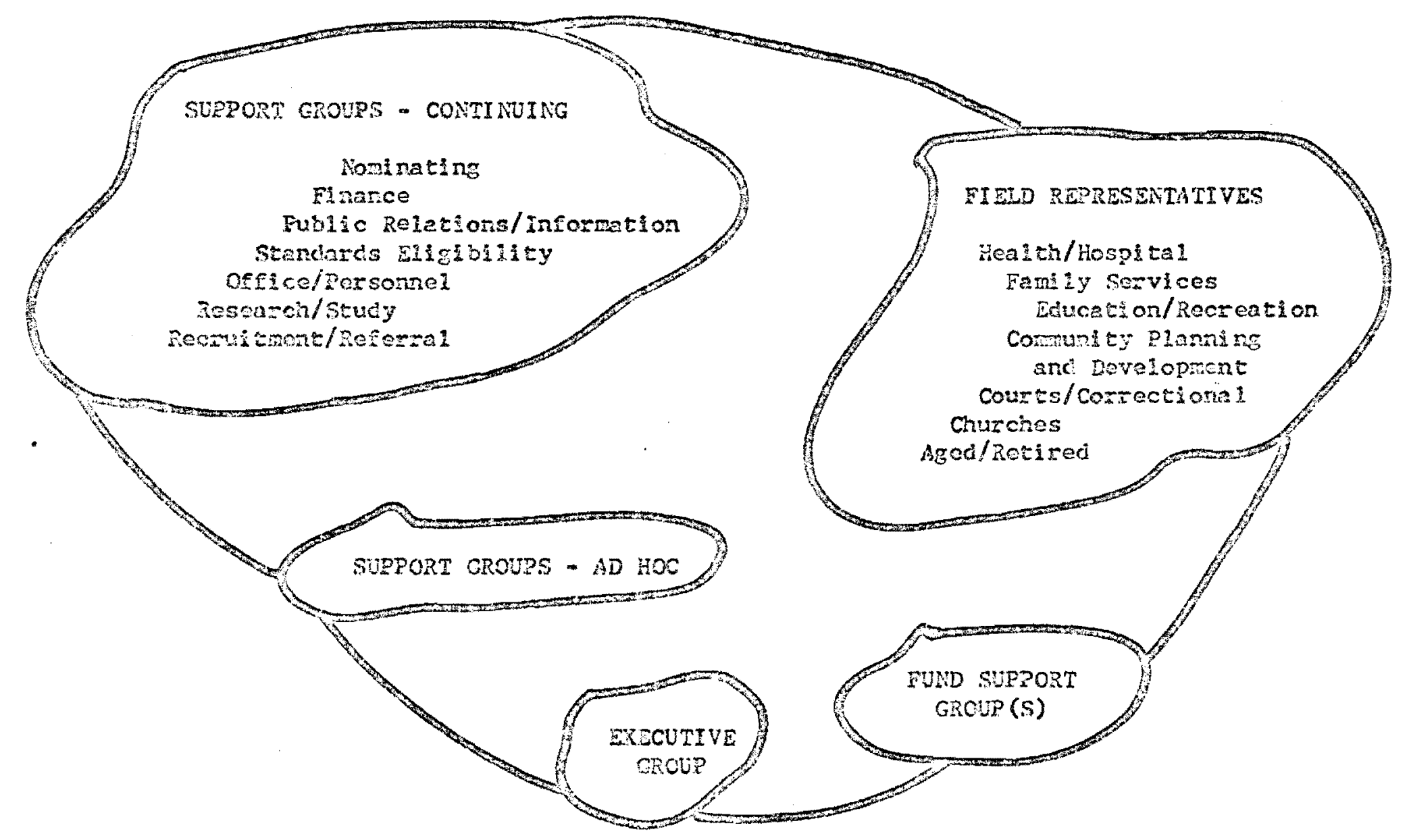

Figure 1. Diagram of the center: bssic Elow lines. 


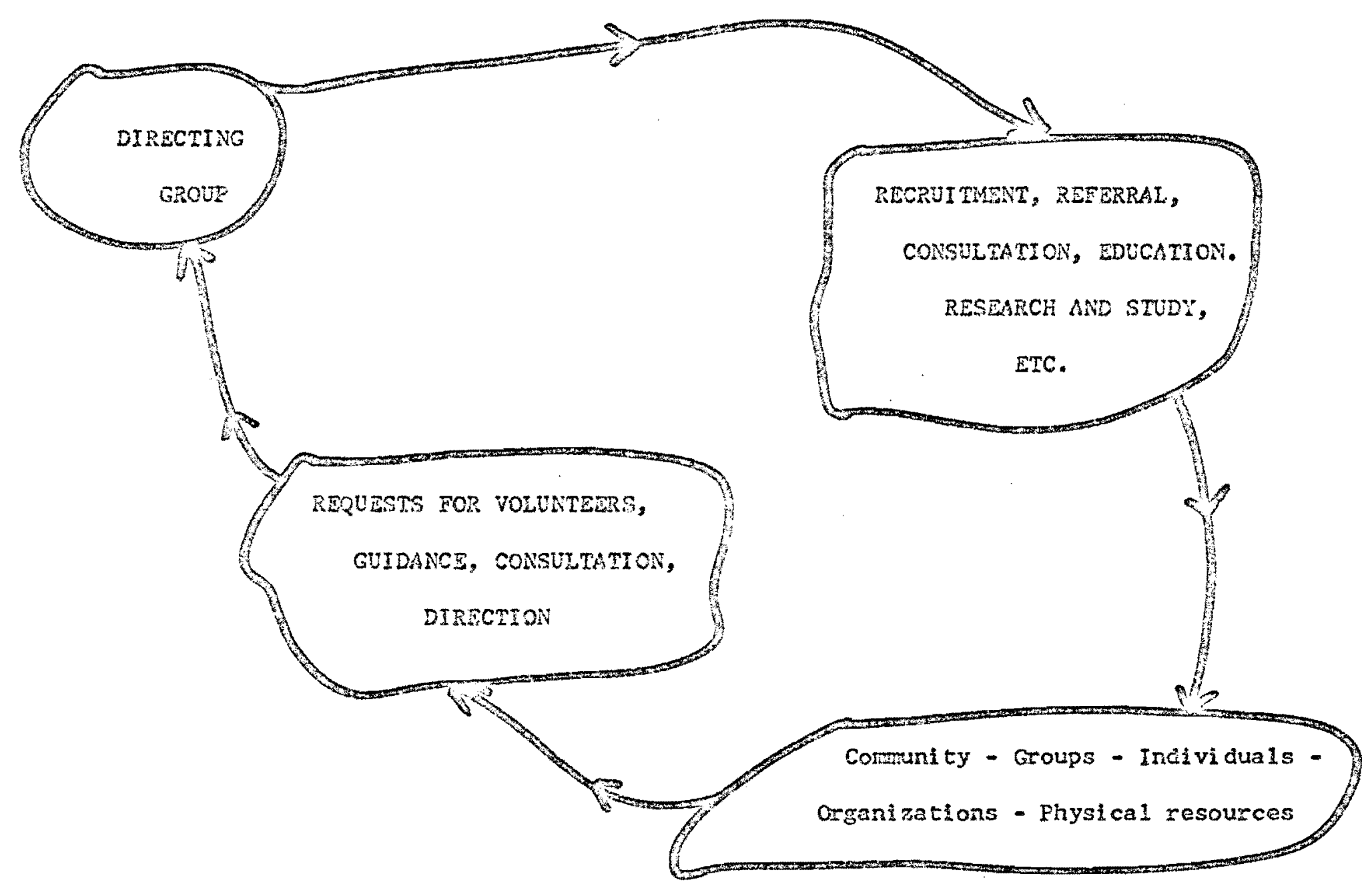

Figure 2. Reiationship of the Center to the cormunity. 


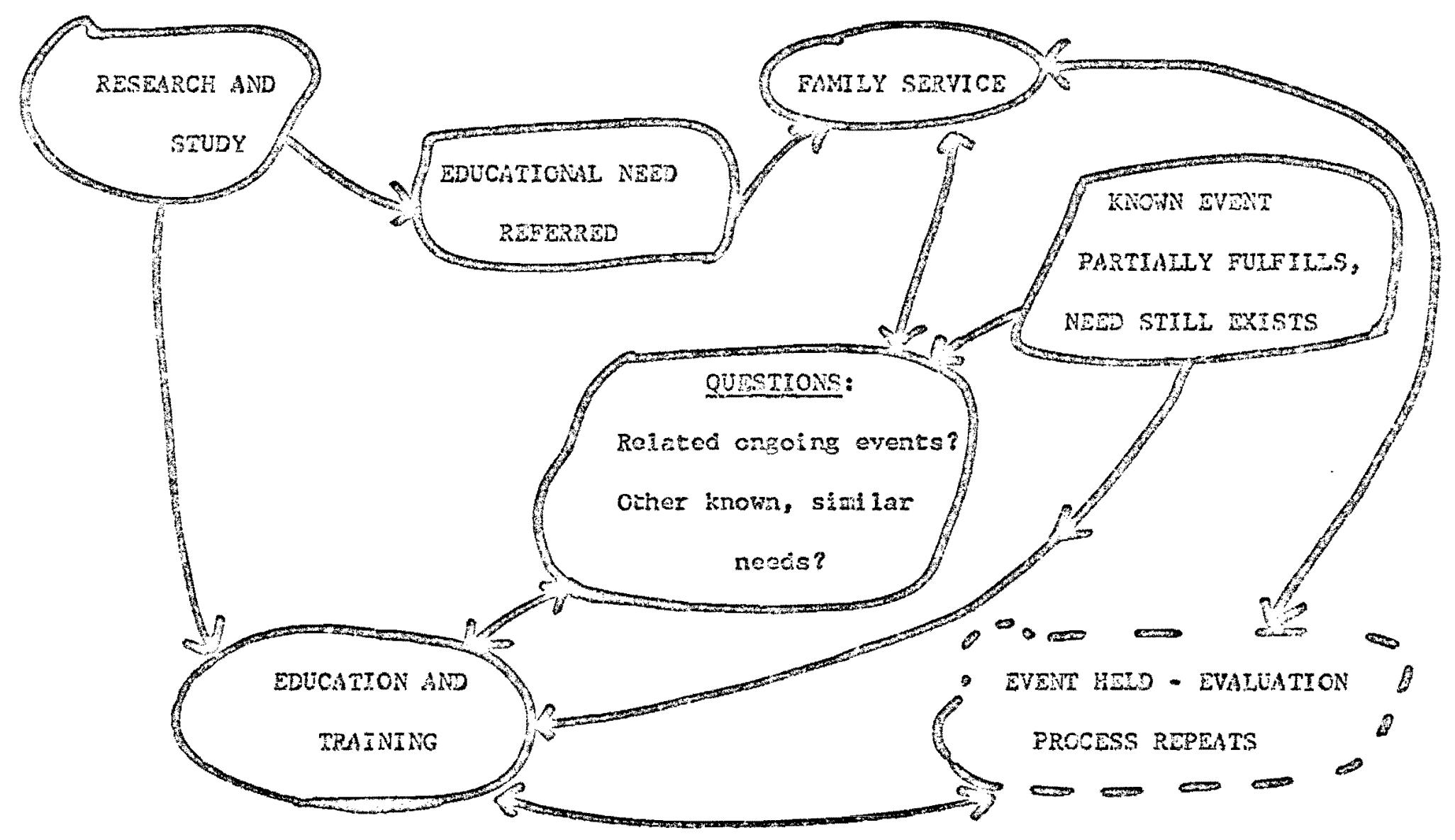

Figure 3. Possible interaction among units of the center. 
IV. SUMTSRY

In presenting the characteristics, functions, and graphic design of the center, the vriter has atterpted of cescribe the requirenents for "people-oriented" programs. Freedon of operation within a framework must not only be in the tone and atmosphere, but also in the structure of a Model that deals with great varieties of human neds.

When combined, these form the Conceptual Hod which the author has intended as description of the idealogical 1 inits of the center. Further details follow in the proposal for the centur. 
CHAPTER IV

PROROAM. FOR A HUIAN RFSOURCE CENTRR

FOR VOLUNARISH

Up to this point, the writer has attempted to describe, in general terms, an organization which could serve as a model for other agencies as well as be a source of specific assistance in the beter utilization of human rerources.

A proposal for a center which is described in greater detail. follows nezt. This proposal has ben devoloped in axder that it will mesh with the bel requidonests and provide a vay to carry out its ideas and programs.

I. FELTIONSHUS BETHEDN FUNCTOONS

AND OPERATYONS

\section{Clarification of Terms}

Used hereln, the word "functions" includes all the axeas of work which the center is organized to perform. The process of the interaction of people, policy, and methods within sn ecological framowork becones the operational managenent of the conter. (29)

In some cases. titles used in both of these categories will be similar and might be confusing to the reader. Hence, the writer will deal next with the functions, followed by further development of the operationa 1. management of the Centes. 


\section{Functions}

Introduced first in chaptor II a aming the requirements for a Center, vere five functions: Cooraination, Research and Study, Consultation, Recruitment ard Referral, Edueation and Training. Together, these functions constitute the totel area of responsilility for the Center.

No one operaticnal unit wal be performing within cach functional area simuglaneously. llowever, each of these functions will be performed by each unt in varying degiees at intervals. At all tines, there will be some involvenenc by one or more interacting units to carry out a furction. Examples and further analysis will help illustrate this interded action petsern.

Recruitrent and Refcral. This will be a now program by one Support Group, but bucation and fraining is inevitabiy involved in this function in such weys as recruiter education and use of refersal records which ma be used in echeational events.

The first step in the learning process is recruitnant. Learning can begin at this nonent, which makes it importrit that close lias son is maintained between the two operational units of the center.

Consultation. This function wili be includet in sone degree it all operating units. Eloments of the consulting frocess are present in the determination of the piobiem atea before reforral of the question or problem can take place.

Lippite expresen the idca thusly: "A consultive relationship is built upon the confidone persons have in one another's integrity, goal oricntation, and comitnent to a problonmsolving process. . " His 
support for the concept also lincluded ". . person-centered leadership as over and against task-centered leadership.. . " (30, p. 8) which must be practiced by units of the center if credibility is naintained in the services to all the using arenctes.

Research and Study. All units will be involved in the function even though major work will be carricd by the support Group having the sane neme. Input muse be varied and cover all operational areas if: output is beneficial. Each unit needs to understand the need for data which can be used in analysis of ways of work and progress measurements. Education and graining. Regardless of which author one reads, there are usually distinctions between the two terms, training and education. Educators tenc to mak this distinction; training". . involves oniy learning that is directly related to job performance, vinile education is concerned with the total human boing and his frisights into, and understanding of, his entire world. . ." (20, p. 1) This writer agrees with the Lippte and This statement in the description of this function in that the argument is a ". . petty one, since both Involve the process of human learning. . ." (20, p. 1)

For the purpose of describing botn the function and the operation, the words are used interchangeabiy or in pairs in this study.

There is potential for leaming each time thore is interaction between two porsons, though tho degree and guality ma vary. Each percon involved in the Center mus assune peronal obligation to continue his or her leaming in trery reasonable vay, while functioning as an operational group leader or member, in order to continue to learn and understand the total workings of the center. 
Coordination. As a function, this perreates cach unt of operation since each must be cognizant of the other's progress and interdependence in specific projects.

In addition, the conter must be constanty alert to its relationships to the laxger commity and find rays to coordinate center projects with those which do not enanate from this source. Each support Group will not only necd to coordinate its activities with all operational unts in the Center but also those in the ecologleal envinonitent.

\section{Hanasuent:}

There are great variations in definitions of mangenent, tost of which are more complex than the whter felt ves aproprate for the Center. Keeping uith the characteristic of slmplicliy, the Erow rodel was found to be the rost appiable. (See Flgura 4) That avthor accented the need for shaxed decision making in managenent and drev a diagramatic nodel bith four components. Pollcy, Methods, and Peeple, within the fremowork of cological liattations can be considered the outer livits for managerent.

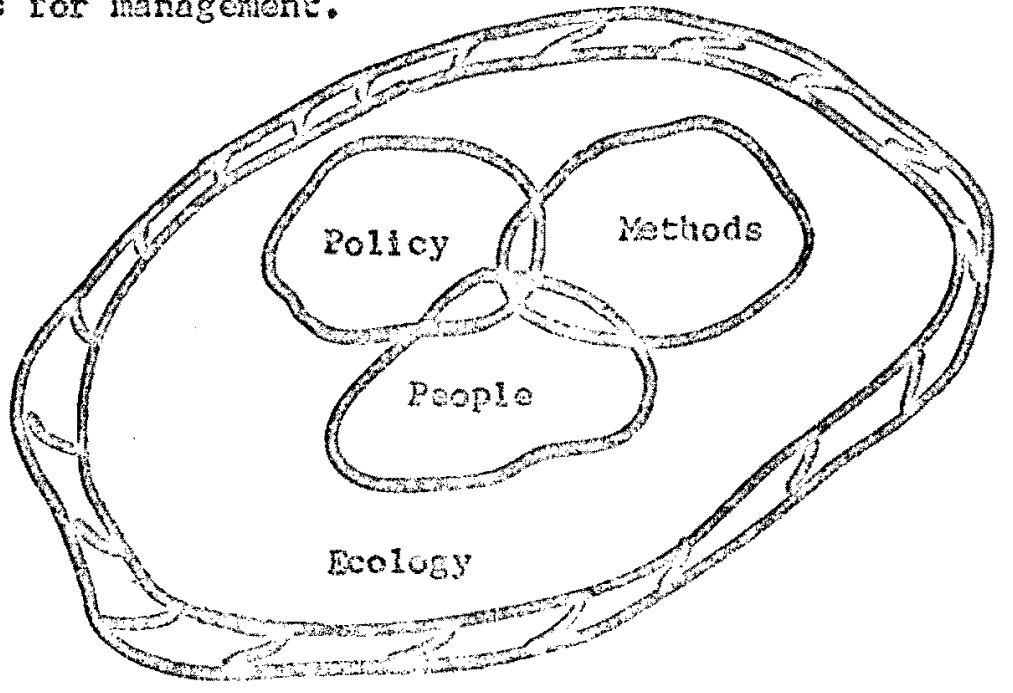

Ilgure 6. Interelations of the compacnts of mangenent. 
Structure Al structure developed to eerry ont programs should encourage a freeton of cpotetion with the simple franewerk. The vodel operates wados the mnagenent of tho birecting Croup, which is divided into forking compononts called unsts. Unt is the word used to designate any segment or part of the center which at any given time has an assignment ox spectio task. Basic units are stpport Groups, Fiteld Representatives, and the Executive Croup. Any spin off or ad hoc graups mat also be units.

Gorationa Practices, In orcter to fulfill the objectives, particular pactices need to be ineorporated into the operations of the Center. These must be denonetrated throughout the entire operation and become part of every componcus's cromen.

1. Appliceble principles of behavional science must be observed evpeoially in regard to adult leaming theorics, and mangenent practices.

2. The cross section of the cormunty should be actively represented in the policy making group. That group should include sweh elements as: a wide age range, ic. high school students to senior citizens; a renge of econonic levels, ie. ADC mothns and otier tax supported persons from the commity; minoxity and ethic groups.

3. Persons who are pad norkers for ageneles affiliated with the Centor, such as a Volunter Coordintor for an Educational or Family Service agency, ny serve as da decting Goup nember. Noninating Support Group menbers need to be alett to eroomeging a balance of both lay and past persomel to be in the Diresting cromp at any one tine. 
4. Learning oppotunitios need to bo continually avajlable in ordex that individual agency programs, ideas, and resources, can be shared with all other agencies.

5. A continuing search needs to be conducted to discover ways to prevent unneessary duplications of all resources, hum and matexial.

\section{ORERATONAL UNATS DESCRTBED}

The personel involved in the Center are not salaried by the Center. Whether or not there is monetary support for specific mombers of the Diacting coup, 1e. txansporcation, day care, or others, these persons axe considered volunteers. The exeeptions ray be the Diroctor's position which my be a full ox past the employee and any clorical personnel rejuized to nairitain staff support for the conten. The latter is not doscribed herein because the ned for assistance could only be detexinhed uron implementation of the center.

\section{DIrecting Groug}

This group is an incorporated body which has the responsibility and authority to direct the activities and prograns which fall vithin the stated puxpose and juristictions. The centeg: is mankged and operated by this group with its services used by groups, organiations or individuals. Preregusite to nombeship on the Direeting croup is comithent to the objectives of the center.

I The vacying state or local lavs will possibly ceuse the design to shift in tites and components. This should not affect the bosic intcrielationsips of functions or units. 
Units. Organizcd into operational intes to accomplish the programs broadiy agreed upon by the Directing Group, each of these has a part of the vork plan to complete. Theso vere referred to in the preceeding section as support Groups, Field Representatives, and the Erecutive Group, and will be next described in greater detail.

Support Gouns, Pernanent and Ad Hoc. These are often called functions or comittees it many of our human service agencies, but the authorities, roles, or perhaps even basio definitions are often not the same among agencies simlar in purpose. Here, the permanent support Groups include basic task areas which will probably be necessary for long range plans of the Directing Croup's total plan of work. Describad in greater detail in the next section, exaples of units within this category are Dublic Relations, Finance, Noninating, and so forth.

Ad hoe Suport Group cover those spedeic Eask areas involving short range plans and are created and terminted as required by the Directing Group.

Each group may have as many persons as noeded, vith its leader as a menber of the Directing Group.

Field Representavives. These assignment axeas are grouped according to simiar specialitics of services, or agency purpose. Hore than one person may be in any specific category, but only the leader is a member of the Directing Group. For ease of communication and simple reference, from this point on, this unit will be referred to as Field Reps.

Executive Groug. This is tha authorized body for any required interim decision making. The Directing froup athorites this sub-group 
to take action and rake judgments with the speoifled limitations. Another role of the group ss the preparation of basic materials for consideration by the Directing Group at their scheduled meetings.

Fund Support Representatives, This unit wight also be grouped with the above wentioned support Groups. The need fow strong liaison betwecn the Directing Grom and its fund source is best done by person-tomperson contacts. This unit may include ropresentatives from one or more major fund support units, each with equal voting privilcges and each pledged to heip with the nork of the center.

Spin-Off Groups. These are temporary groups which mat be faned by units to implenent special terminal projects, and work directly with its parent group. This unt way have one or more persons serving as advisors or halpes in any wy possiblo or neoded. It is crpected chat a spin-ofe tace from one or more Support Grours or Field Reps may be cause fox a spin-off group to be formed to inplonent th and subsequenty be consicered important enough to be a pexmanent support croup.

\section{RESPONSIBILTIES OE THE DIREOTIKG GROUP}

The following statements are purposely brief. They axe not specific ways of nork but rathex jou tescriptions to ciefine areas of responsibility.

Executive Grout

The respones bility of the Wecutive crowp is to act upon such matters as designted by the Directing Croups in omergencies or routinely, during meeting intervais of the Directins Group. 
Chairman. This person presides at all Executive and Direoting Group mectings. In addition, he or she should accept specific, intexpretive responsibilities for the cucation of groups and organizations through presentations which help ro broaden the base of understanding of the center. The chaiman plans agendas, organizes the metings, works closely with staft and designates time and purpose of reports from all units.

Vice Chairngn, As the one who presides in the absence of the Chatrman, ho or she also assures the same interpretive role as 1 isted above for the Chaiman. Mo or she also assists the Chairnan by giving help where ox when required to all units in the blrecting croup.

Recorder. This job is to koep descriptive and accurate notes of al1 Decutive and Directing Group reetings. There needs to be an agreement on acceptrble fozmt for all recordings in order to enhance rapid reference. The person assigned here cerves as an information source to the Chaiman in regard to these records.

Treasures. Technical aspects of fund accounting, check writing and signing are the tasks aseigned to this person. Depending upon the size of the operation, the bookkeper works clocely with the trecturer.

Directos. The responsibilities of the pirector are veried and deternined by the neds of the center. Ceneraliy, they include iluplerenting progrens as planned and delegated by the chairman, providing support to the Chairman and all support group leaders with knowlolge, exportisa, and staff servicos which mond vary with the needs and abilitics of porsomel involved in the center. This person must be able 
to comunicate with individuals and groups and holp develop and mantain

a continuing operational service conter.

In addition, the Drector supervisos any of ice staff and directs the work wich is a support service to the cencer. This is a salaried position and ma be full or part time.

\section{Supporting Groups}

Nominating. Interviewing and selecting persons for vacancles as they occur, subritting then to the Dixecting croup for conslderation and approval constitutes the prinary responstbilitiss for this support unit. In order to do this, constant attention must be paid to observing activities in the comunity, interviowing potontial birecting Group nembers, helpers or advisors. Additional informtion on the group wil be found in section IV.

Finsnce. Roquesting funds from a fund ralsing source, based on sound operational needs, providing the chamel for direct information in regard to supplenental fund raish if requice, reporting on the status of the operation at designated times, mintalning an open, dixect working relationship with Fund suppont Reps, gives this unit a vital role. It also must be in close commication with other units to provide the purpese for fund requeses.

public Information/geletions. This unit sorves as intiator or processer, either in content os ideas for all local media. It provides the Dircoing Group with ideas and metods helpful in the implementing of decentralized activities. -

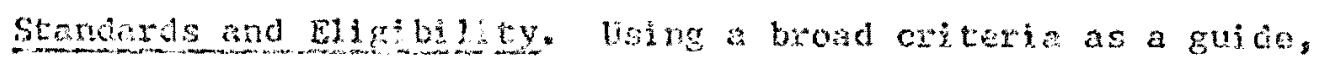
this unit consules with outsido agoncles end/o* untes of the center 
regarding the responsibilities, privileges, and ways of work. It revicus and accepts request: for services from the conter by testing these agalnst the criteria. In cases of doube, the paoblems are referted to the Drecutive Group which nalies final judgant. Additional critaria data vill be found in Section VIT.

Office and Personnel. This unit seeks candidates for the position of director, when necded, and recomends preferences to the Directing Group for employnent. It vorks vith the Director in obtaining quality offlce services, persomel, equipnent necessary to efficiently carry out office functions.

Recognition and retention are included in this unit's responsibility. However, this unte reeds to direct lieas and be willing to experinent. Retchtson begins with recruttont and the feeling of belonging, and the reiationsip inge the individus has toward the agency. Hence, this unit needs to kork closely with the Recruitment and Referral unit to assure continuty in intent and practice.

Education ald Taining. Developing and initiating learning opportunities as requested includes both internal and extornal responsibilities. Seeking informtion in regard to learning events avallable in the commity and actively encouraging interagency events is another major task area, as vell as secking perconnel and material resources fron ongoing operistions to carry out inibiated events.

Recruitnent end lefergel. Consucting recruitment projects which

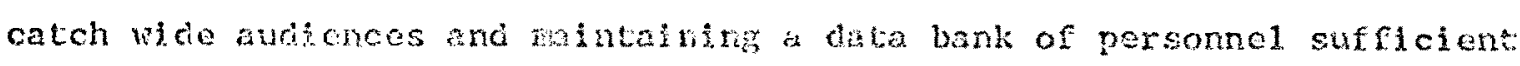
to provide accuracy, raliabiity, and rapid retrieval, for both recuite and using agoncies is ptimary to this unit. Wrking closely with 
Research and study for retenton data and devoloping systons for quick referrals and follow up wil help to cmable each volunteer to receive a thoughtful intervier, more thorough consultation, and beter placenent.

Fund Support Representetive(s). ihis support unit is specifically plamed to provide the personal contact betweer fund support groups, such as UGN, and the Center. The purpose is to provicie information or explanations portinont to prograns, trends, anti restrictions currenty planned by the Fund Support Group (s). The Fund Spport Rep should vork closely with the rinanse support Group, however, this does not give the Fund support Group control of the Center's cxpenditures.

since fund raising is a highly specialized operation, the center needs to be affilated with acceptable, quajified group or groups carcying out this function.

\section{Field Representatives.}

The over all responsibility for cach person in this assigtinent area is to work vith designated groups involving volunteers in order to determine their current and future needs for personnel, lcarning events, or corsultive services, and to provide a direct channel to the birecting Group and any unit therein for satisfaction of these needs.

Rationale for gxouping them according to program similarities is: 1) it enables the Field Rop to speclaltze in like groups with simiar needs; 2) there axe greator possibilities for sharing learning events, and consultive sessions; 3) there is mone tendency to encourage interagency cooporation when the field Rep neets with the personnel and those individuals are cble to gct acquabutede 
Health and Hospical. Ihis includos pubite, private, mental, physical, and culucationa: groups whose purposes fall under these titles. Education - Recreation. This includes formal, informal, educational and group work services for youth or adults.

Family Services. This includes public, private, assistance agencies, child care, fanily aid, and any other related services within this category.

Comnun ty Plaming and Develoment. This includes civic, cultural, neighborhood and urban renemal projects, and Comanity Bction Programs.

Courts and Correctional Institutions. All Juvenile Hones, adult Institutions, or simlint behavio: modification programs cone undes this category.

Churches - Counci 1 of Churches. The ecumenical organization which exists should be the group through which this represcntative norks. Individual reguests can stili be harnded.

Agen and Regired. Clubs, retirement centers, and convaloscent homes are the types of facilities grouped herc.

\section{TERAS OR MSSIGMHNTS}

The Executive croup includes the Chaiman, Vice Chairman, Recorder, Director: and three Support Group leaders; three Field Reps, one Fund Support Rej, or approsimetejy eleven persone. (See Nigure 1, p. 39)

For menbers of the Directing crowp, toms or assignmonts run for three years and should be stagered ot tho begining of the operation so that each year some nen persons asstume responsibilities. Terms should be no more than three years with at least die year interval before beconing 
eligible for remelection. In those intorins, fonet brecting Goup members may be working mewbers of a unit, but not leading one. Re-election must be to a different wit than before in this case.

The structure, with limited constraints of detailed job descriptions and rules, allows frecom of action in the implementation of tasks.

Voting on the single slate is cone by the birecting Group. Careful consideration by the Nominating Surport Group to achieve crosscommity representation, with tenure restrictions, w11 keep active, vital persons coning into the organization. The popular desire to have voting done by large groups such as polling representatives from all using agencles, or wieepread nemberships, too frequently results in blind voting and useless crouis. If the Contex's objectives are pursucd, stagnation by pexpetuation is highly whikely. The process itself vill simulate the desired resulits.

\section{REFLECTON OF CROSS-COMMUNTY PROFILE}

The profile of the Dixceting Group should be indicative of the commity's profile of adult population. This would mean that effort must be made to have the Nominating support Group soek persons representative of minority groups, different cconomic backgrounds, including those receiving public grants and those fron different geographical arcas. The major criteria for eligibility are that they be willing to give service, and learn at the same time. This profile rust also include young people in high school or colloge who may be either in active roles with the Directing Goup or nembers of the units. It is 
fmperative that we include the younger age group in major decision making roles as vell as iaplementing ones.

\section{AUDT IOR MAL UNTS}

Given the chance, nost oxganizations become very involved and complex and tend to spend more time on piocess than goals.

Consistent with the flexible, fluid design necessary to achieve the tone of the center are the following guide lines each unit should consider at frequent intervals. They are presented as quostions which help to establish a perscral imvolvenent on the part of the unit's menbers.

1. Wil. this project ox activity help ruffill the objectives, or plan of nork of the center?

2. How will this activity involve or relate to anothe: unit's plan of work?

3. How are we planning to share implications of this involvenent for optimun meshing of plans?

4. When are our check points planned?

5. What is our time table for completion?

With cach unit considering these points, thore may need to be joint meetings of units or at least meetings of the leaders to prevent a collision course or lack of coordination of plans.

Chechoints. One of the simple ways to help avold commication barriers is the uos of tho otrokpint plan. At designated times, or places, in any given plan, a group should stop to check progress. 
Evaluations at these intervals might cause changing, modifying, or eliminating entire portions of a plan. It should be used by the Directing croup and all untes as a way of rork to keep action in line with gaals.

\section{STANDARDS AND EUIGIBLLTTY CRITERIA}

As nentioned earidex in this chapter, the center needs to have criteria for serving using agencies as vell as some guides for accepting requesting agencies' requcsts, in order to move toward fulfilling its objectives. Though both sets can be simple and undemanding in many things, in the area of combenent to the objectives of the center, there should be no compronise in effort by the using ageney.

\section{Criteria cuides}

Requesting agencies neod to be able to accept the following criteria before the center can act on its requests. It must agxee to:

1. accept the objectives of the center,

2. estabiish a plan for education and supervision of voluntcers,

3. comply vith simplo documentation required for commication.

4. In lieu of the above, it must have requested consultive help? fron the Center to assist with compliance of the criteria.

The proceso for this should be in looping with the basic objectivos and operationd tore of the center. Rather than make it a screening action, it should bo a heiping one. In practice, criterion two frequenty becomes an involved series of requirenents, such as only a salariet porson my be a discotos of volunteers, or there nust be an 
integrated series of training experionces avalable. This causes undue hardship on the agencies just beginning to develop volunteex programs, when attempting to satisiy such requirenents.

\section{EVAUUATTON}

Evaluation of effectiveness, an important function of any encity, is relative as perceived by the observex. As mentioned in chapter II, Splegel (2, p. 4) feels strongly that bias is the factor which causes blocks to scientific approach. llowever, prevention of atagnation in programing can be accomplished through effective evaluation processes which are built into a system at its ineeption. If there be agreenent on objective, sols to ind thon, and critoria for guidenco, projected in advance, there can be measurement of acconpistment. This cyclical process should be part of the amund seli. asscssment of the center.

\section{Iypes of loasurcments}

Some practitioners criticize the "nubbers game", a comon title given to the practice of counting each contect or intervicu equally with other kinds of services. They feed this cheates a bias in the neasurements and renders the results useless. Though this writer agrees that mixing kinds of data is not sound, measurenents must bo both qualitative and quantitative to adequetely define changes which ma have taken placc.

Quantitative, Data showing the mber of intorvens, referrals, consultations and simar services can be kept by each unit in specific test poriods, ard be gathored for doowenting xoports. These should not: be used whowe furtier supert or cise the "numbers gand will be in complete control. 
Qualitative. This is a more difficult area to test. Such techiques as attitude surveys, observations of involvement, participation frequency, randon sarpling of personsel from using agencies, all can be external neasuring devices. These ituns matched vith budgetary controls, can be used to draw attention to veak or strong spots for further analysis.

Tools have been developed for internal measurements of roles and relationships of viluntees and staff (31) and personal growth and self Inventory mensurements. (32) dids such as these should be used both by Center persomel as vell as using agencios.

\section{DEVLOENENTAL PHASES}

Lippite (9) developed a moder wheh this autior has adapted. The thee phases of organizationd. grovth and the critical concerne paranount in each ane sumarlzed as follows:

Birth: to create a rew organization, to survivo as a viable system

Growth: to gain stability, reputation, develop pride

Maturity: to achiove uniquenoss and adaptailility, to contribute to society.

He writes that the consequences of each groweh stage not meeting the criticai concerns will lead eventually to failure of the organization. $(9, p .39)$

Grouth of the conter

Phase one. Fron the "bin"th" of the center, using projections stated thus fax, Lmediate attention mat be given to declaring 
priorities for action. Among the areas logically concerned are the education of the Direoting Croup, connunication systen, both internal. and external, the information retricvai systens, and evaluation processes.

Phase Two. As soon as growth begins, the need for stability, reputation for reliable output, and pide in accomplishent can be measured. The periodic revicu of priorities in prozrams then forms the basis for shifting priorities in the total plan of nork.

Phase Three. Achieving uniqueness vill be done by the creation of new prograns and innovative planning in foxner areas of void in services. Adaptability can be denonstrated by evaluations of existing services and eliminating those not then required or which axe duplicated.

Fach nev plan of work will be influenced by the preceedigg one and the growing base of acomplistments mill foed bark to patticipants thereby opening additional avenucs for exporimental projects.

Evaluations must be consistant and checkpolnts frequent in crder to assure conflutey with fever conunication gaps.

\section{SUMMEYY}

By diagrans, the author has attonpted to shor the centcr: as a structure. Hith verbal descriptions, the vriter has atteingted to describe the unts, how they interrelate, as vell as each unit's relationship to the functions of the conter.

Before lemohing prograns, proviston mat be mode for evaluations to be conducted at interwas, based upon gonle set by the pirecting Group, and masurement criceria. Trase must be in fanden with the 
objectives which constitute the purpose for the center. Wativation for the contex's impienentation mat: be the beliof in, and villingness to connit to, its broad objectives. Conviction of thetr value or nerit is prerequist te to the menbership and participation as a menber of the Directing Growp. 


\section{CHAPTER $\mathrm{V}$}

SUMARY

\section{CONCLUSIONS}

The extenstve mental exercise brought about by experiences during the development of the Conceptual hodel and the resultant proposal, created an all too frequent desire to begin implementation of the idens. Dividing the creation of a Center fxorit the reality of operation was a most difficult restraint for the witer. As a result, the author condudod that the center should be inplomented and thereby tested. Each hour spent in research and witing reinfored this belief. In the process of implementing the plan for the center, the wrter feels thore vould be a high probability for the following recults.

\section{Community Changes}

If the center nere cieveloped as described, the results would be vieved as improvements in the commuty. Among these: 1) a growing number of citizons gould learn vays to becoma involved in commity service, 2) the base of involvement would widen to include groups not now participating, 3) the close agency interaction vould heip to discovex voids end cuplications fin services, a) there vould be a neutral ageney serving as the stimulus for interagoncy sharing of their resources, 5) the attidue townd adult education would take e different turn to include the field laboratory of comunty service as a major lmact area. 


\section{Inmovation and Expexinentation}

Innovation and experimentation vould be the "vay of 1 ife" for the Directing Group. Unisle a long established agency vith a wide spread membership expecting scrvices perceived in tiadicional ways, the Center would be in a position to develop relationstip contracts with the requesting agency to assist in specific areas of need rather than attempt to be everywere at once. This nould provide additional models from which othor agencles could learn.

\section{Spin-off Groups}

Decentralization would be considered as a development of the Center. Spin-off groups made in the same inage as a parent group would not necessarily hove to follor the same petcertis of innovation. Adaptive designs wold need to be tried and tested wich vould groove vith the min center, though have individualistic characteristics. Any rethods or approaches which help to achleve objectives could be constderch pilot ox exporimental ventures and could easily cone about with the freedon of creativity built into the center.

\section{Inserversonal Relations}

An organization with few rules and restraints, such as the wodel and center: suggest, nould necessartly have to leep the objectives in vieu which could movide an atmosplare where interpersonal truste vere strengthened, if the progran survivel. There would be litcle cover for those individuals not puling thei port of the load. This could only result in the growing strergth of the center, or totel fallure. The 
key would be to develop trust and practice the process of sharing to the fullost.

\section{RECONWNDATIONS}

\section{Recormended Studies}

In the process of developing the study, the author found areas needing further research and development, which if carried out, would contribute to increased understanding of voluntarism.

1. A study should be conducted of stafe and volunteer roles in specific geographical areas. Loewonberg's pilot study in 1965 showed maxked relationship in the increased anount of detailed staff support and the decrease of substantive participation on the part of volunteers. (16) He moposed, hovever, that various local studies should be conducted to ascertatu if there were geographical or other differences which would influence results.

2. A study probing the personal atticules toward voluntarism in general, and volunteer programs and education of voluntecrs, conducted anong a variety of categories of professional persons, nould provide data which would help in planning ways to pronoto volumtarisu as well as improve that which already exists.

3. Incressed nubers of interagency activities involving joint planning, executing, and evaluatirg, need to be held in order to determine measurable benefits. Cameful peparations for analysis mist be made in alvanee and be integral parts of each session to assure an objective study. 
Reconmendations Directiy kezated

to Mode1 Jimplementation

1. There needs to be gateder crossadisciplinary sharing. Mode1s used successfully by Peace, comps personind, for example, could be adapted to many different 1 ife stylo comanities, $(33,34)$ Effort needs to be made to develop proceiures to enabe this sharing to be more easily affected.

2. Experimontation rist be continually conducted in the use of methods for encouraging motivation of non-participants to becono involved in commity cndeavor. This would result in the increase of interdependence in a comanity. Haturity of a socicty is based upon the comblnation of indepencence and interdependence. To prevent special interest groups fron retarding progress for persond gutn for a few it is recessary to have large scale involvenet of poople steking to understand and know about factors which would make up the problen areas. (1, pp. $226-227)$

III. TKENDS AREETYNG VOLUNTARISH

There are definite tronds to be considered which will have jmpact on the total. field of voluntarish. Each vall affect the testing of the Model for the Centex as vell as every other currently active volunteer service agency. The identification of sorse of these yeneral areas seens vital as the parting contribution of the study.

1. Even with the hopes and aspiratione for laxge scale cltizen involvement, we mat still face the trends toward wide scale employnent of the traditionally ciominant voluntere component, the housewives. As they begin to retrain for employnent, full or part the, this detracts 
from their leisure time, the source previcusly avallable will shrink in numbers, and compotition for their tine will increase.

2. The further away from core areas that conwuting takes us, the longer it will take to go to and from work, also detracting from available leisure time. (l, p. 229)

3. Notivation, in people now considered by both themselves and society as being disinterested, vill have to be increased. Stimulation probably will need to be related to tangible, inmediace results such as better employment chances or physical corforts.

4. There will have to be increasch attention paid to child care facilities to relieve the mother while she learns how to volunteer. Even though she wants to help, a large segnent of our: population cannot personally fund the cost of helping others. Similar conceris vill need to be given to nales for incldental expenses, if not dild care, should the current trends of family lite continue.

5. If the forecasts for shorter work woeks continue, another factor may begin to compensate for the increased enploynent of individuals, especially women. Wre men will have leisure tine, and can become part of the potencial for voluntest involvenent. This could rell change the current situation of the greatew number of women over man in the volunteer ranks.

6. Increased effot will be plsced on nore efficient organization of scrvices by agencies. There will have to be better preperation bofore involvenent of new peromel, because competition vill increase and vointecrs will move to the places where satiefaction is most quickly obtained. 
1. Cohen, Nathan E., ca. Tre Cition Volunters His Responsibility, Role and oprortunicy in Wodern Socisey. Nen York: Hanper and Brochors, 1960 .

2. Spiegel, Hans B. C., ed. Citizen Participation in Urban Development. Concepts and Issues, Vol. 1. Selected Radings Series Seven, Vashington, D. C.: NTL Institute for Applied Behavioral scionce, 1968.

3. Voluntary Action News. Newsletter, Vol. 1, No. 2, November 1970.

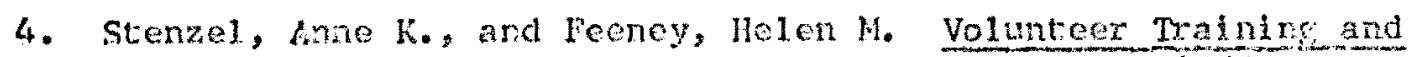
Development. New York: Seabury Prese, Inc., 1968.

5. Bergevin, Paul. A Philosophy for Adult Bducetion. Nev York: Seabury Press, Inc., 1967 .

6. Jipptet, Gordon I. Individualicy and Tecmogk. Reprint Sexies. Washington, D, C.: Leadership Rescmees, Ine., $196 \%$

7. Aoust Ronction Association of U. S. Ao Better Eoaxds and Comiteces. Leadexship Parphlet No. 14. hushington, D. C.: Adult Equcation Association of U. S. A., 1957.

8. Nayior, Hariet H. Volunteers Poday, Findins, Training, and ant rogkng wieh them. Nev York: Association Eress, 1967.

9. Lippitt, Gordon L. Gonazational Kereval, dohieving viablity in A Changing borld. New York: Appleton-Century, Crofts, Educstional Division, 1969.

10. Johnson, Gulon Griffis. Volunceers in Communty Segice. North Carolina: Secman pross, Durhas, 1967 .

11. United Comunty hunds at comsils of tmerica. The volunteer

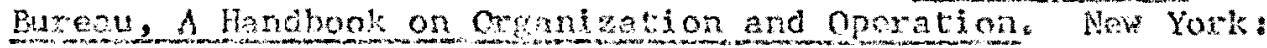
inted Comming Winds and Councils of Americe, 1967.

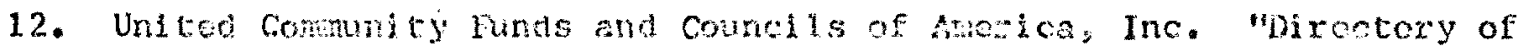
Voiunteen Burcase" Now Yosk, 1970, (Minoogrophed)

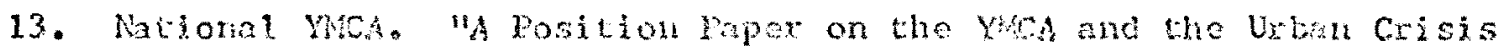
With six Rocomencavions" Nov Vork: Urban Action Comiteed, Mich, New Yomli City, 1268. 
14. Tnowles, Micolns. "How Andragogy Norks in Leadership Training in the Girl scouts." Adult Jeadershis, Oetober 1968. Washington, D. C. : Adult Ehucatior Association of U. S. A.

15. Schindlor-Raimm, Eva. "The day of the Voluteer Is Really Here!" Speech delivered at the Voluntedr Conforence, Scattle, Vashington, october 1968. (hin nographed)

16. Loewenberg, Frank $h$.The Diroctors: A Pilot Study of Volunteer Participation in Decision hing in Voluntary Group service Agencies." Unpubif shed Ph.D. Dissertation, Vayne state University, 1965 .

17. Douglah, Dharaned $A$. "Factors Affecting Adult Paricipation in Educational Activities and Voluntary Fontal organizations." Unpublished ph.D. Dissertation, University of Wisconsin, 1965.

18. Wahn, Alfred J. ed. Netghborhood Infotmation Centers. New York: Columbia Univereity School of Social rork, 1966.

19. Social Welfare Planning Council. "Gujelineso" Prepared by Community Volunteer Sorvice, New Orleans, La. February 1964. (kimedgrapheo)

20. Titis, Leslie E., and Lippitt, Cordon L. Learning Theories and

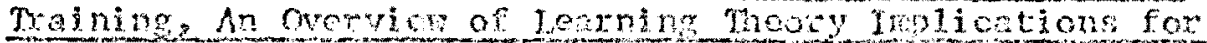
the Training bi rectos. Regrine Series. Vashington, D. C.: Leadership Resources, Inc. 1966.

21. Spindlor, George D., ed. Elucation and culture, fnthropological Approaches. New York: Holt, Rinehart and Winston, 1963 .

22. Jahoda, Marie; Deutsch, Morton; Cook, Stuart W. Research Wethods in Soclal Relations. Part I. New York: Dryder? Press, 1951.

23. Elucatonal Research Information Centor. Thesauxus of LRIC Eescriptors. 2nd ed. Washington, D. C.: U. S. Department of HEW, Bureau of Research, April 1969.

24. Portland State University Faculty Wives' Survey. "Volunteer Quegtionnajxe." Wetropolitan Portland, oregon, 1969.

25. Warbington, Helen Le "Receateh $3 n$ Adult Fducotion Prograns in some Frivato Agencies in S. W. Wahington nut megon." Researeh Frojech, Dortland state univecsity, 1970. (Typerititon)

26. Division of Contimuing Edication. Oregon Association of Volunteer Leaders Information letter. Portland Conter, Portland, Dre. June 5,1969 . 
27. Citizen's Conntited "Rroposal for is Voluntoer Bureau." Portland, oregon: hy-Comaty Commatity Council, Januery 1970.

(Photocopled)

28. U. S. Jayeee clube, "Do Sonething Iardbook", Implomentation Guide for A Netiont woject, 1070.

29. Buwn, havis s. Inderstanding the Wragerent Functicn. Monograph Series. Mashingion, D. C.: Lradership Resourco, Inc., 1066.

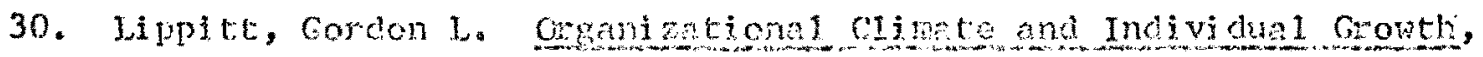
the consultive process at Wort. Rertint Series. Washington, D. C.: Leadership Rosomoes, Inc., 1950.

31. Council of Natonal cetuzations for Adujt Education. Probing Volunteer-stafe Relations. Testing kt, New York: Assooiation Press, 1963.

32. Blansfield, Hichel G., and Jippitt, Gotdon L. Personal Growth Inventoy. Washington, D. C.: Leadership Resources Inc.. 1966.

33. Doms, Janes E. "Fables, Fantasies ard Falures in Cross cultural

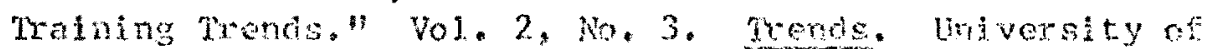

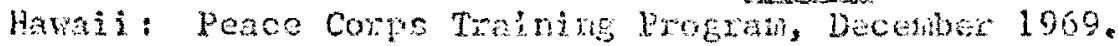
(ED 034 935)

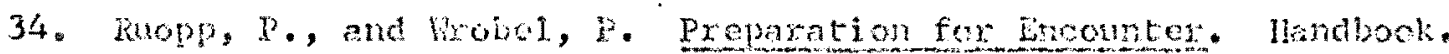
Virgin lslands: St. Thoma Caxibuean Resenreh lastitute, June 1.267. (DD 029 1.93) 


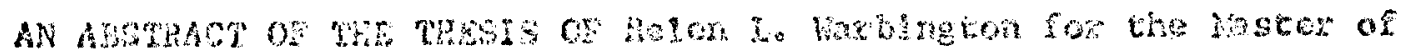

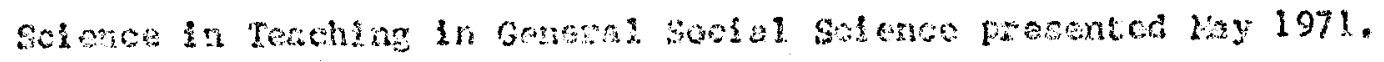

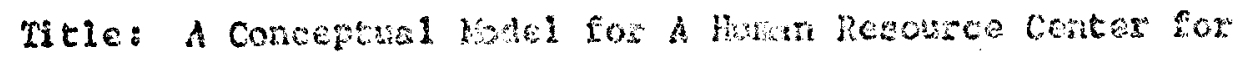
Volutitaten

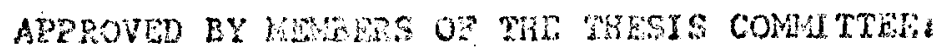

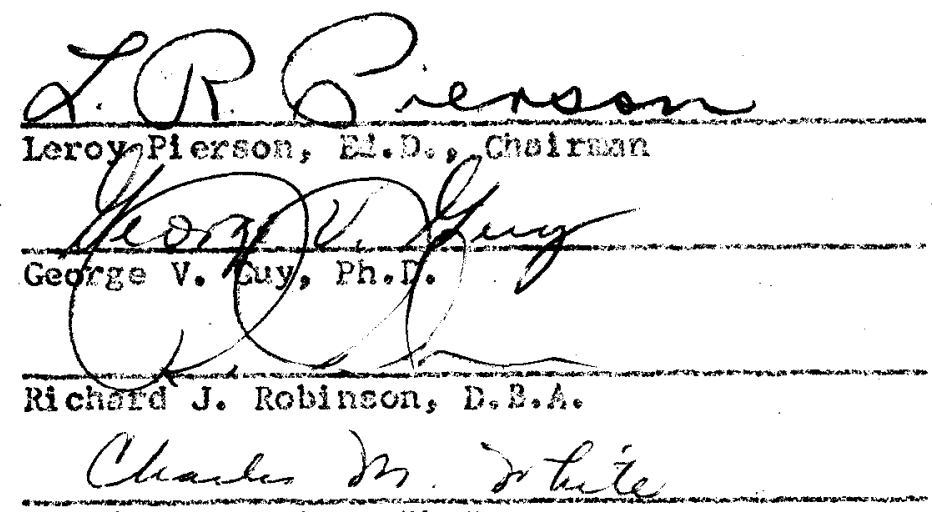

Charles M. Whites PhoD.

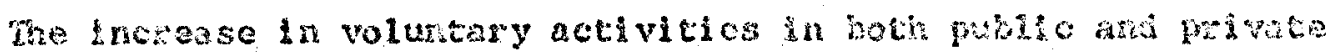

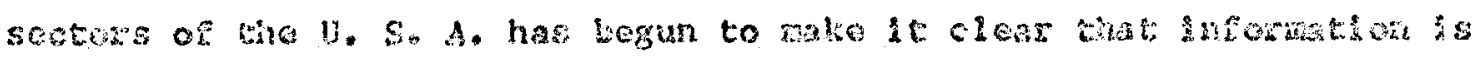

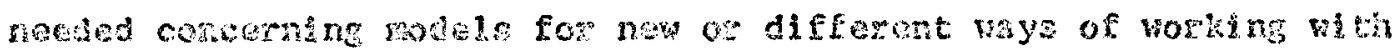
peogie fa velumeas agencleo.

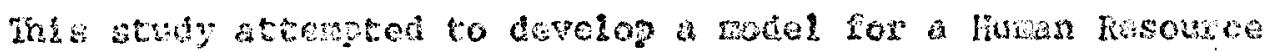

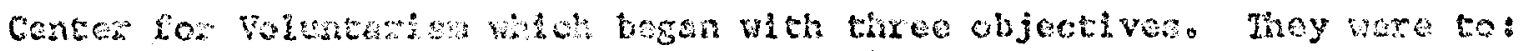

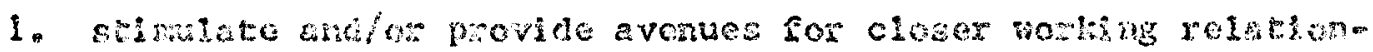

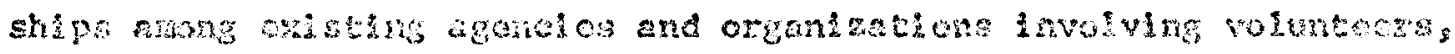

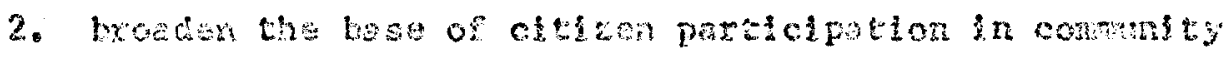
servingess

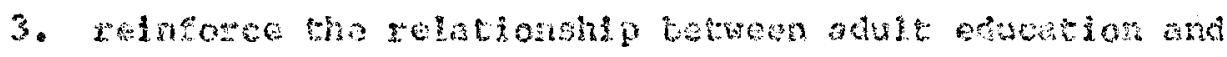

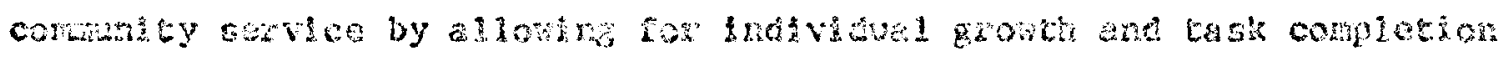

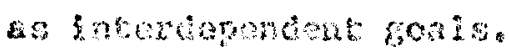


Fundanental statenents underlying the puryose for developing a Wodel included the following:

1. Involvement of citizen volunteers is a valuable facet of the American cultura! heritage, and is unigue in ite application.

2. An adult's responsibility as a citizen is to become involved in the community to woxk toward improvements for all individuals.

3. Education is the principal avenue by which this can be accomplished because: (a) learning results in behavor change, (b) behviot chenge is necessary for cultway growh and progress. Fon this, a Model was developed which described in general terms What tones, atmosphere, end rebrionships vere necessaxy to achieve bhe gonls. In addition, a proposal was sode for more specinc details bo: the reruirenents of the pirecting Group and its comporents.

Data for the study was obtained fron docunented literature primarily from 1960 to 1970 , as vell as personal caperiences of both the writer and many colleagres in the rield of voluntary comaniey savere agencies.

The witer concluced that the proposed Cancer could have sore lasting, lositive effecs on a commity by botig both a model for othox commuity servica agercios as well as an action agency which could develop innovative and experimentel weys os vork. 


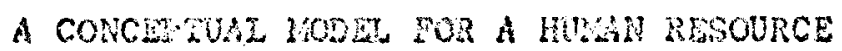

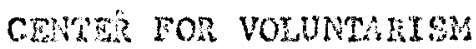

\section{by}

HETEN L. WARETKTON

A thesis subiatted in partal fulfillment of the regut renants for tite drge of

HASTE or SCJUHCE IN TERCHWN

in

GENGRAL SOCIAL SOLRNCH

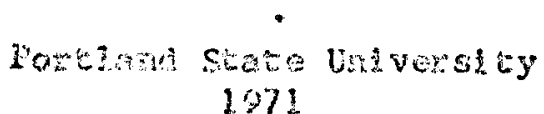

1971 
TO THE OFEICE OF GRADUATE STUDIES:

The rembers of the Commetee approve the thesis of

Holen t. Harbington presented hy 1971.

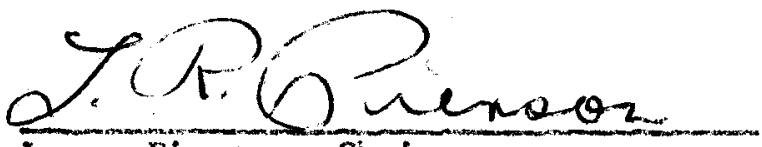
Leroy, pierson, chairran

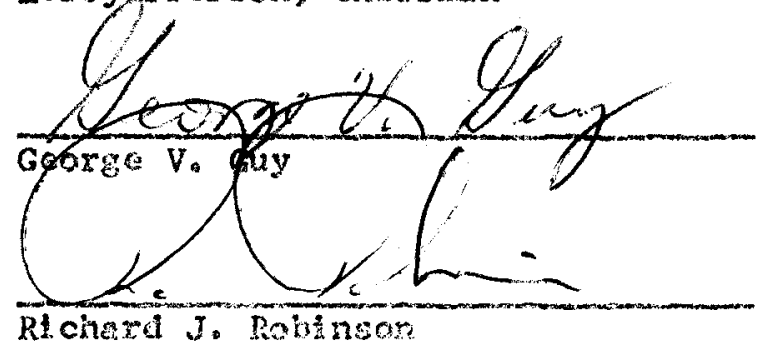

$$
\text { Cleme. dr, jute }
$$

Chardes Mo frite

\section{APREOTED:}

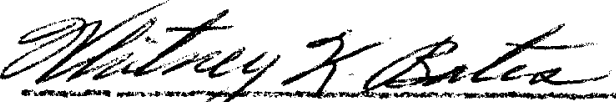

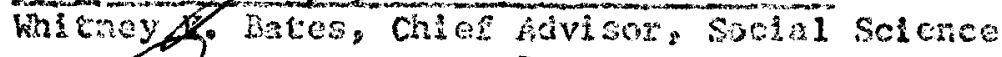

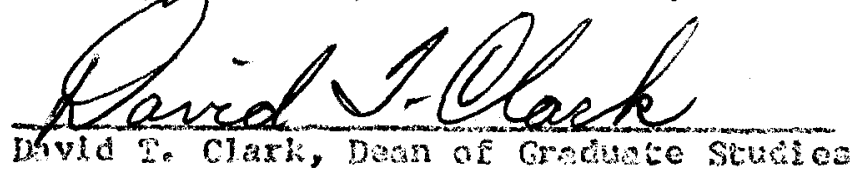

